\title{
The Atmospheric Chemistry and Canopy Exchange Simulation System (ACCESS): model description and application to a temperate deciduous forest canopy
}

\author{
R. D. Saylor \\ National Oceanic and Atmospheric Administration, Air Resources Laboratory, Atmospheric Turbulence \\ and Diffusion Division, 456 S. Illinois Ave., Oak Ridge, TN 37830, USA \\ Correspondence to: R. D. Saylor (rick.saylor@noaa.gov)
}

Received: 15 August 2012 - Published in Atmos. Chem. Phys. Discuss.: 21 September 2012

Revised: 12 December 2012 - Accepted: 26 December 2012 - Published: 21 January 2013

\begin{abstract}
Forest canopies are primary emission sources of biogenic volatile organic compounds (BVOCs) and have the potential to significantly influence the formation and distribution of secondary organic aerosol (SOA) mass. Biogenically-derived SOA formed as a result of emissions from the widespread forests across the globe may affect air quality in populated areas, degrade atmospheric visibility, and affect climate through direct and indirect forcings. In an effort to better understand the formation of SOA mass from forest emissions, a 1-D column model of the multiphase physical and chemical processes occurring within and just above a vegetative canopy is being developed. An initial, gas-phase-only version of this model, the Atmospheric Chemistry and Canopy Exchange Simulation System (ACCESS), includes processes accounting for the emission of BVOCs from the canopy, turbulent vertical transport within and above the canopy and throughout the height of the planetary boundary layer (PBL), near-explicit representation of chemical transformations, mixing with the background atmosphere and bi-directional exchange between the atmosphere and canopy and the atmosphere and forest floor. The model formulation of ACCESS is described in detail and results are presented for an initial application of the modeling system to Walker Branch Watershed, an isoprene-emission-dominated forest canopy in the southeastern United States which has been the focal point for previous chemical and micrometeorological studies. Model results of isoprene profiles and fluxes are found to be consistent with previous measurements made at the simulated site and with other measurements made in and above mixed deciduous forests in the south-
\end{abstract}

eastern United States. Sensitivity experiments are presented which explore how canopy concentrations and fluxes of gasphase precursors of SOA are affected by background anthropogenic nitrogen oxides $\left(\mathrm{NO}_{\mathrm{x}}\right)$. Results from these experiments suggest that the level of ambient $\mathrm{NO}_{\mathrm{x}}$ influences the pathways by which SOA is formed by affecting the relative magnitudes and fluxes of isoprene oxidation products emitted from the canopy. Future versions of the ACCESS model are planned to be multiphase, including gas- and aerosolphase chemical and physical processes, to more fully explore these preliminary results.

\section{Introduction}

Forests are a critical component of our planet's global ecosystem, occupying a little more than 30 percent of total land area (Potter, 1999), comprising 50-60 percent of total carbon biomass (Malhi et al., 2002), accounting for 40 percent of the total solar energy captured by green plants (Perry et al., 2008), and generating 50 percent of total terrestrial photosynthesis (Malhi et al., 2002). The dynamic, bi-directional exchange of trace chemical species between forests and the atmosphere has important impacts on both the forest ecosystem and atmospheric composition, with potentially profound consequences on air quality, climate and global ecosystem functioning. In particular, forests are a dominant source of volatile organic compound (VOC) emissions into the earth's atmosphere. Of the total non-methane VOC emissions of $1300 \mathrm{Tg} \mathrm{Cyr}^{-1}$, close to 90 percent is 
thought to originate from biogenic sources (Goldstein and Galbally, 2007) and forests account for 90 percent of all global biogenic emissions (Naik et al., 2004). As a result, by themselves, global forests account for nearly 80 percent of all non-methane VOC emissions. As the dominant source of biogenic VOC (BVOC) emissions, forests thus have a substantial impact on local, regional and global atmospheric chemistry, since BVOCs play key roles in the formation of both ozone $\left(\mathrm{O}_{3}\right)$ and secondary organic aerosol (SOA) (Fuentes et al., 2000) and secondary roles in the global carbon cycle (Goldstein and Galbally, 2007) and the oxidizing power of the global atmosphere (Poisson et al., 2000).

Recognizing the vital role that forests play in atmospheric chemistry, several intensive field measurement campaigns have been undertaken to better understand the chemical and physical processes that contribute to and control the exchange of trace species between forest canopies and the atmosphere. As examples of field campaigns conducted in temperate North American forests, the PROPHET (Carroll et al., 2001; Tan et al., 2001), CELTIC (Karl et al., 2005), BEARPEX (Wolfe et al., 2011a), and CABINEX (Kim et al., 2011; Steiner et al., 2011; Bryan et al., 2012) campaigns have all provided a wealth of new information about forest canopy chemistry and exchange, but have also raised many new questions (see Bryan et al., 2012 for a concise summary).

After the initial realization that BVOCs can have a major influence on the formation of $\mathrm{O}_{3}$ in rural and urban environments (Trainer et al., 1987; Chameides, et al., 1988), Gao et al. (1993) constructed a coupled chemistry (69 reactions), first-order-closure turbulent diffusion one-dimensional (1-D) column model of an idealized deciduous forest canopy to investigate vertical profiles and fluxes of $\mathrm{O}_{3}$, isoprene and other chemical constituents. Gao and Wesely (1994) extended Gao et al.'s (1993) model by using a second-order closure approximation for vertical turbulent diffusion and found that vertical fluxes of isoprene and $\mathrm{O}_{3}$ were not greatly influenced by the enhanced treatment of turbulence. Doskey and Gao (1999) used the original model of Gao et al. (1993) to analyze vertical profiles of isoprene, methanol and $\mathrm{O}_{3}$ measured above the Harvard Forest in Petersham, Massachusetts, during July 1996. Their results exhibited only a minor impact of chemistry on isoprene fluxes near canopy top and that vertical fluxes decreased rapidly with height, resulting in little isoprene escaping from the planetary boundary layer (PBL) into the free troposphere.

Makar et al. (1999) developed a 1-D canopy chemistry column model to study the chemical processing of BVOCs within and above a temperate deciduous forest near Borden, Ontario, Canada. Employing a chemical mechanism with a more extensive description of isoprene and monoterpene oxidation reactions than the Gao et al. (1993) model (a total of 268 reactions of 79 species), they simulated vertical profiles, fluxes and process budgets of isoprene, $\alpha$-pinene, $\mathrm{O}_{3}$, $\mathrm{HO}_{\mathrm{x}}$, organic peroxy radicals and other BVOC oxidation products. In contrast to Doskey and Gao (1999), they concluded that neglect of isoprene chemical losses within and just above the canopy could result in substantial overestimation of isoprene fluxes from the Borden forest, while the amount of $\mathrm{O}_{3}$ produced was minimal at the site because of low $\mathrm{NO}_{\mathrm{x}}$ levels. Stroud et al. (2005) enhanced the model of Makar et al. (1999) (including sesquiterpene emissions and chemistry; enhanced treatment of radiative fluxes) and applied it to the analysis of measurements made in a Loblolly pine plantation at Duke Forest, North Carolina, as part of the CELTIC field program in July 2003. In contrast to Makar et al. (1999), they found that a relatively small amount of isoprene reacted chemically within and just above the canopy. For the sesquiterpene, $\beta$-caryophyllene, they estimated that 70 percent reacted before transport to the free troposphere with little sensitivity in that value with respect to background anthropogenic pollution levels.

Stockwell and Forkel (2002) and Forkel et al. (2006) applied the Canopy Atmospheric CHemistry Emission (CACHE) model to a Norway spruce forest at Waldstein, Germany, and simulated 1-D profiles of temperature and water vapor in addition to gas-phase chemistry of trace species within and above the forest canopy. Gas-phase chemistry was simulated with the Regional Atmospheric Chemistry Mechanism (RACM) of Stockwell et al. (1997) and simulations were used to analyze data collected at the Waldstein site during the BEWA2000 field campaign (Klemm et al., 2006). Forkel et al. (2006) estimated with CACHE that chemical reactions reduced BVOC above canopy fluxes by $10-15$ percent compared to simulations with no chemistry and that maximum $\mathrm{O}_{3}$ values were enhanced by $15-20$ percent due to BVOC emissions. Bryan et al. (2012) applied the CACHE model to measurements made in the CABINEX 2009 field measurement study at the University of Michigan Biological Station PROPHET site (Schmid et al., 2003) and found that uncertainties in vertical mixing parameterizations are critical components in interpreting observations from a canopy chemistry field measurement study.

Mogensen et al. (2011) used a 1-D column model (Boy et al., 2011) to analyze measurements from the SMEAR II measurement site (Kulmala et al., 2001) in southern Finland in a boreal forest. The model (referred to as SOSA) simulated the evolution of momentum, heat and moisture in the PBL and included chemistry derived from the Master Chemical Mechanism (MCM) (including 2140 reactions of 761 species representing chemistry of isoprene, monoterpenes and other BVOCs). Mogensen et al. (2011) found that the model under predicted measured sinks of hydroxyl radical $(\mathrm{OH})$ above the forest and suggested that the missing reactivity was due to unknown BVOCs or uncertainties in the modeled mechanism.

Wolfe and Thornton (2011) and Wolfe et al. (2011a, b) used the Chemistry of Atmosphere-Forest Exchange (CAFE) model to analyze measurements made during the 2007 BEARPEX field campaign. CAFE is a 1-D vertically 
resolved chemical transport model that was designed to simulate a young Pondersa pine canopy located in the Sierra Nevada Mountains near the University of California's Blodgett Forest Research Station (Goldstein et al., 2000). CAFE utilizes a subset of the MCM v3.1 chemical mechanism including reactions for isoprene, monoterpenes, sesquiterpenes and other BVOCs, but no anthropogenic VOCs other than propanal (a total of 2085 reactions of 632 species). In their comparison of BEARPEX 2007 measurements with model results, Wolfe et al. (2011a) noted in particular that the model significantly underestimates $\mathrm{OH}$ concentrations and requires an unknown enhanced radical recycling mechanism to correct this under prediction. However, recent results of Mao et al. (2012) indicate that $\mathrm{OH}$ concentrations previously measured in many field campaigns (such as BEARPEX 2007) by laser-induced fluorescence in low-pressure detection chambers were likely over estimated by a factor of two, thus lessening the model under prediction of Wolfe et al. (2011b). It is also noted in Wolfe et al. (2011b) that ozonolysis of very reactive BVOCs within the forest canopy may influence a variety of important chemical pathways, including $\mathrm{OH}$ production and fluxes of BVOC oxidation products (and thereby may influence the fluxes of SOA precursor species).

In contrast to the Eulerian-based modeling approaches described in the preceding discussion, a few studies have employed Lagrangian-based stochastic modeling to explore reactive exchange of BVOCs from the canopy to the atmosphere (e.g., Strong et al., 2004; Rinne et al., 2007, 2012). In particular, Rinne et al. (2012) used the Lagrangian approach along with measurements of oxidants in a Scots pine forest to estimate the within-canopy chemical loss of isoprene, $\alpha$-pinene and $\beta$-caryophyllene. Of the three representative BVOCs, their model results suggested that the sesquiterpene $\beta$-caryophyllene exhibits the greatest withincanopy chemical degradation, while isoprene exhibits negligible chemical loss. Interestingly, a pronounced diurnal variation in chemical degradation was observed, especially for $\beta$-caryophyllene and $\alpha$-pinene, with reactions with $\mathrm{NO}_{3}$ radical driving the nighttime loss of these BVOCs within the canopy. Rinne et al.'s (2012) results suggest that a complete accounting of BVOC fluxes from forest canopies may require flux measurements and modeling over full diurnal cycles rather than the temporally-limited flux measurements that have been performed in the past.

It is clear from the preceding very brief review of prior studies of forest canopy chemistry and exchange that there is still much to be understood about this very important topic. Moreover, most previous investigations have focused on gasphase chemical processes and the effect of BVOC emissions from forest canopies on $\mathrm{O}_{3}$ and PBL fluxes of isoprene and other primary BVOCs. Now that it is becoming clearer that isoprene, in addition to terpenes, contributes to SOA (Carlton et al., 2009) and that aqueous- or wet-aerosol-phase chemical processing may contribute to total SOA concentrations (Lim et al., 2010; Hallquist et al., 2009), multiphase modeling and measurement studies of forest-atmosphere exchange are needed to analyze the importance of these SOA formation pathways. To arrive at a better scientific understanding of the complex chemical and physical processes of forest-atmosphere exchange and provide a platform for robust analysis of future field measurements of these processes, a process-level, multiphase model of the atmospheric chemistry and physics of forest canopies is being developed. This model, the Atmospheric Chemistry and Canopy Exchange Simulation System (ACCESS), will be used to investigate various aspects of forest-atmosphere exchange and chemistry including gas- and aerosol phases. In the work reported here, a preliminary gas-phase-only version of the model is described and results from an initial application to a mixed deciduous forest in the southeastern US (SE US) is presented. The model is described in Sect. 2, its application to an isoprene-emission-dominated mixed deciduous forest is described in Sect. 3, results are presented and discussed in Sect. 4, and conclusions and future model development and applications are described in Sect. 5.

\section{Model description}

ACCESS is a general column modeling system that can be used to simulate one-dimensional multiphase atmospheric chemistry, vertical turbulent transport and biosphereatmosphere exchange processes from the earth's surface to the top of the planetary boundary layer (PBL). The model, written in Fortran 90, has been designed to be modular and flexible with individual processes included or excluded as desired via an input simulation control file and with the science content of processes and inputs easily upgradeable without modification of the basic code structure. Application of ACCESS to a particular simulation configuration (i.e., vegetative canopy, chemical species and mechanism, meteorology, background or free tropospheric concentrations, etc.) is accomplished via a combination of input data files and peripheral tools. In this work, ACCESS is applied to an isoprenedominated, mixed deciduous forest canopy in the SE US in an initial attempt to better understand how background anthropogenic sources may impact the production of biogenic SOA in this area. In particular, this work focuses on how the above canopy fluxes of gas-phase SOA precursor compounds may be influenced by the level of background $\mathrm{NO}_{\mathrm{x}}$ concentrations. For this application, the governing equation of ACCESS is given by

$$
\begin{aligned}
\frac{\partial C_{i}(z, t)}{\partial t} & =E_{i}(z, t)+A_{i}(z, t)+D_{i}(z, t) \\
& +R_{i}(z, t)-\frac{\partial F_{i}(z, t)}{\partial z}
\end{aligned}
$$

where, $C_{i}(z, t)$ is the vertical gas-phase concentration profile of species $i ; E_{i}(z, t)$ is the emission rate of species $i$; $A_{i}(z, t)$ is the rate of mixing of species $i$ with a defined 
background concentration; $D_{i}(z, t)$ is the deposition rate of species $i ; R_{i}(z, t)$ is the rate of chemical transformation of species $i$; and, $\frac{\partial F_{i}(z, t)}{\partial z}$ is the rate of vertical turbulent mixing of species $i$.

Parameterizations for the processes in Eq. (1) that influence the vertical profiles of gas-phase chemical species within and above a forest canopy are described in detail in Sects. 2.1-2.5.

The model domain is discretized with $1 \mathrm{~m}$ vertical resolution within the canopy and an expanding stretched grid from the top of the canopy $\left(h_{\mathrm{c}}\right)$ to the maximum height of the PBL (h) so that the vertical grid node locations $\left(z_{k}, \mathrm{~m}\right)$ are defined as

$z_{k}=\left\{\begin{array}{cc}k-1 & 1 \leq k \leq h_{\mathrm{c}} \\ h_{\mathrm{c}}+\left(h-h_{\mathrm{c}}\right)\left[\frac{\alpha^{\left(k-h_{\mathrm{c}}-1\right)}-1}{\alpha^{\left(N-h_{\mathrm{c}}-1\right)}-1}\right] & h_{\mathrm{c}}<k \leq N\end{array}\right.$

where $k$ is the grid point index beginning at the surface, $N$ is the total number of grid points, and $\alpha$ is a parameter which determines the rate of vertical stretching of the grid and is determined separately for each domain and canopy height. For the domain used in this work, $h=2000 \mathrm{~m}, h_{\mathrm{c}}=24 \mathrm{~m}$, $N=81$, and $\alpha=1.08182$.

Integration of the ACCESS governing equation is performed using operator splitting (Strang, 1968; Ropp and Shadid, 2009), each process being integrated sequentially over a user controlled integration time step (nominally $60 \mathrm{~s}$ ) using an appropriate process-specific sub-time step. Emissions, deposition and background mixing are integrated with a simple explict Euler method; integration of turbulent vertical diffusion employs the implicit method of Patankar (1980) with Crank-Nicolson time discretization; and chemical transformations are integrated with the Fortran 90 version of VODE (Brown et al., 1989; http://www.radford.edu/ thompson/ vodef $90 \mathrm{web} /$ ). For stiff systems of ordinary differential equations, VODE uses a variable coefficient backward differentiation formula (BDF) algorithm that is both highly accurate and computationally efficient.

Inputs to ACCESS include meteorological variables (including temperature, pressure, humidity, mean horizontal wind speed, vertical turbulent flux data, canopy attenuation of actinic radiative flux and photosynthetic photon flux density - PPFD), forest canopy morphology (including the vertical profile of leaf area density, biogenic volatile organic carbon emission factors, and soil emission factors), and background trace species concentrations (including species mixed from the remote background and concentrations of species above the PBL). Meteorological variables for a simulation can be provided from observed data, from a vertically resolved land surface model or can be generated from user defined parameterizations. Outputs from ACCESS include vertical concentration profiles, fluxes and process budgets of all simulated trace species and calculated emissions rates and deposition velocities. The model can be run in either steadystate mode at a prescribed fixed time or over a full diurnal cycle or in prognostic mode from a given set of initial conditions and allowed to evolve deterministically over time as a function of dynamically-varying input data. Simulations of the current version of the modeling system are run on a single processor in either a Mac OS X or Linux-based environment. Since chemical transformation calculations at each layer are independent during each overall model time step, future versions of ACCESS are planned to be parallelized across multiple processors and/or cores to enhance the model's computational efficiency and usability.

\subsection{Chemistry}

The chemical mechanism of the model is derived as a subset of the University of Leeds Master Chemical Mechanism (MCM) v3.2 (Saunders et al., 2003) and includes 62 inorganic reactions $\left(\mathrm{NO}_{\mathrm{x}}-\mathrm{O}_{3}-\mathrm{NO}_{\mathrm{y}}-\mathrm{HO}_{\mathrm{x}}\right)$ and near-explicit chemistry for methane, six biogenic hydrocarbon species (isoprene, $\alpha$-pinene, $\beta$-pinene, limonene, $\beta$-caryophyllene and 2-methyl-3-buten-2-ol) (MBO) and ten anthropogenic hydrocarbon species (ethane, propane, $n$-butane, ethene, propene, trans-2-butene, benzene, toluene, $m$-xylene and $o$ xylene). The complete mechanism includes 6988 reactions of 2429 integrated species and four non-integrated species $\left(\mathrm{O}_{2}\right.$, $\mathrm{H}_{2} \mathrm{O}, \mathrm{CO}_{2}$ and $\mathrm{H}_{2}$ ). The full mechanism listing is provided in the supplement to this article. ACCESS includes Pythonbased tools to automatically generate Fortran 90 code suitable for direct insertion into the chemistry modules of the modeling system, based upon the text listing of the mechanism once it is downloaded from the University of Leeds MCM website (http://mcm.leeds.ac.uk/MCM/). Using these tools, the chemical mechanism of ACCESS can be quickly updated or modified.

Rate coefficients of the inorganic thermal reactions were updated to the recommendations of Sander et al. (2011), with the exception of the association reaction of $\mathrm{NO}_{2}$ with $\mathrm{OH}$, which was updated with the recommendation of Mollner et al. (2010). The rate coefficients of the organic thermal reactions were taken as provided in the MCM v3.2. Photolytic rate coefficients as a function of zenith angle and altitude for the 1066 photolysis reactions in the mechanism were mapped to MCM photolysis reactions from those used by the MOSAIC model (Zaveri et al., 2008). Within the canopy, photolytic rate constants are scaled by the attenuated actinic flux as described in Sect. 3.

\subsection{Emissions}

For the initial application of ACCESS reported here for a temperate, broadleaf forest in the SE US, isoprene is assumed to be the dominant BVOC emitted from the canopy (Goldstein et al., 2009) and other emitted BVOCs are neglected in this initial analysis. Emissions of isoprene from the canopy are based on the formulation of Guenther et al. (1993) 
and (1995) as follows:

$q^{\text {isop }}(z)=q_{\mathrm{b}}^{\text {isop }}(z) \cdot \gamma_{\mathrm{T}}(z) \cdot \gamma_{\mathrm{L}}(z)$

where, $q^{\text {isop }}(z)$ is the canopy isoprene emission rate (molecules $\mathrm{cm}^{-3} \mathrm{~s}^{-1}$ ); $q_{\mathrm{b}}^{\text {isop }}(z)$ is the canopy emission rate (molecules $\mathrm{cm}^{-3} \mathrm{~s}^{-1}$ ) prior to the application of temperature and light correction factors and is given by

$q_{\mathrm{b}}^{\text {isop }}(z)=E_{\mathrm{b}}^{\text {isop }} \cdot \mathrm{LAD}(z) \cdot C_{\mathrm{f}}$

where, $E_{\mathrm{b}}^{\text {isop }}$ is the effective leaf-level isoprene emission rate $\left(\mathrm{nmol} \mathrm{m}{ }^{-2}\right.$ leaf s $\left.{ }^{-1}\right) ; \mathrm{LAD}(z)$ is the canopy leaf area density profile $\left(\mathrm{m}^{2}\right.$ leaf $\left.\mathrm{m}^{-3}\right)$; and, $C_{\mathrm{f}}$ is a units conversion factor.

The temperature correction factor, $\gamma_{\mathrm{T}}$, is calculated as

$\gamma_{\mathrm{T}}(z)=\frac{\exp \left[C_{t 1}\left(T(z)-T_{\mathrm{s}}\right) /\left(R_{\mathrm{gas}} T(z) T_{\mathrm{s}}\right)\right]}{1+\exp \left[C_{t 2}\left(T(z)-T_{\mathrm{m}}\right) /\left(R_{\mathrm{gas}} T(z) T_{\mathrm{s}}\right)\right]}$

where, $T(z)$ is the vertical canopy leaf temperature profile (K) (assumed to be equal to the air temperature profile in the initial version of ACCESS); $R_{\text {gas }}$ is the ideal gas constant $\left(=8.314 \mathrm{~J} \mathrm{~mol}^{-1} \mathrm{~K}^{-1}\right) ; T_{\mathrm{s}}=301 \mathrm{~K} ; T_{\mathrm{m}}=314 \mathrm{~K}$; $C_{t 1}=95000 \mathrm{~J} \mathrm{~mol}^{-1}$; and $C_{t 2}=230000 \mathrm{~J} \mathrm{~mol}^{-1}$.

The light correction factor, $\gamma_{\mathrm{L}}$, is calculated as

$\gamma_{\mathrm{L}}(z)=\frac{\alpha C_{\mathrm{L}} \operatorname{PPFD}(z)}{\sqrt{1+\alpha^{2} \operatorname{PPFD}^{2}(z)}}$

where, $\operatorname{PPFD}(z)$ is the canopy-attenuated photosynthetically active photon flux density ( $\mu$ mol photons $\mathrm{m}^{-2} \mathrm{~s}^{-1}$ ); $\alpha=0.0027$; and, $C_{\mathrm{L}}=1.066$.

Soil NO emissions in ACCESS are based on the formulation of Yienger and Levy (1995) as suggested by Wolfe and Thornton (2011) and are temperature dependent with a maximum emission rate at $30^{\circ} \mathrm{C}$,

$E_{\mathrm{NO}}=\left\{\begin{array}{cc}E_{\mathrm{NO}}^{\mathrm{b}} \cdot \frac{T_{\text {soil }}}{30^{\circ} \mathrm{C}} & T_{\text {soil }}<30^{\circ} \mathrm{C} \\ E_{\mathrm{NO}}^{\mathrm{b}} & T_{\text {soil }} \geq 30^{\circ} \mathrm{C}\end{array}\right.$

and are introduced into the domain in the lowest model layer. Soil temperature is approximated as a linear function of the air temperature in the lowest model layer (Williams et al., 1992),

$T_{\text {soil }}=0.84 T_{1}+3.6^{\circ} \mathrm{C}$

The basal soil NO emission rate, $E_{\mathrm{NO}}^{\mathrm{b}}$, is an input variable for the simulation, but typically may range from 0 to $13 \mathrm{ng} \mathrm{N} \mathrm{m}^{-2} \mathrm{~s}^{-1}$ (Steinkamp and Lawrence, 2011).

\subsection{Deposition}

Leaf level dry deposition is treated with the formulation of Meyers et al. (1998), where the species-specific dry deposition velocity, $v_{\mathrm{d}}$, as a function of height within the canopy is computed with

$v_{\mathrm{d}}(z)=\frac{1}{r_{\mathrm{s}}(z)+r_{\mathrm{b}}(z)+r_{\mathrm{m}}}+\frac{2}{r_{\mathrm{b}}(z)+r_{\mathrm{c}}}$ where, $r_{\mathrm{s}}, r_{\mathrm{b}}, r_{\mathrm{m}}$, and $r_{\mathrm{c}}$ are the leaf stomatal, boundary layer, mesophyll and cuticular resistances $\left(\mathrm{s} \mathrm{cm}^{-1}\right)$, respectively.

The stomatal resistance formulation of Zhang et al. (2002) is used,

$r_{\mathrm{s}}(z)=\frac{r_{\mathrm{s}, \min }\left(1+b_{\mathrm{rs}}^{\prime} / \operatorname{PPFD}(z)\right)}{f(T) \cdot f(\mathrm{VPD}) \cdot f(\psi)} \cdot \frac{\mathcal{D}_{\mathrm{H}_{2} \mathrm{O}}}{\mathcal{D}}$

where, $r_{\mathrm{s}, \min }$ is the minimum leaf stomatal resistance $\left(\mathrm{s} \mathrm{cm}^{-1}\right) ; \quad b_{\mathrm{rs}}^{\prime}$ is a canopy specific empirical constant ( $\mu$ mol photons $\mathrm{m}^{-2} \mathrm{~s}^{-1}$ ); $\mathcal{D}_{\mathrm{H}_{2} \mathrm{O}}$ is molecular diffusivity of water vapor in air $\left(\mathrm{cm}^{2} \mathrm{~s}^{-1}\right)$; $\mathcal{D}$ is the molecular diffusivity of the deposited species in air $\left(\mathrm{cm}^{2} \mathrm{~s}^{-1}\right) ; f(T)$ is a temperature correction function (dimensionless); $f$ (VPD) is a water vapor pressure deficit correction function (dimensionless); and, $f(\psi)$ is a water stress correction function (dimensionless).

Both $r_{\mathrm{s}, \min }$ and $b_{\mathrm{rs}}^{\prime}$ are canopy specific parameters which are given by Wesely (1989) and Zhang et al. (2003) for a deciduous broadleaf forest as $1.0 \mathrm{~s} \mathrm{~cm}^{-1}$ and $196.5 \mu \mathrm{mol} \mathrm{m}^{-2} \mathrm{~s}^{-1}$, respectively. An empirical formula for the molecular diffusivity of water vapor in air as a function of air temperature, $T(\mathrm{~K})$, and pressure, $p(\mathrm{~Pa})$ is given by Tracy et al. (1980) as

$\mathcal{D}_{\mathrm{H}_{2} \mathrm{O}}=0.226\left(\frac{T}{273.15}\right)^{1.81}\left(\frac{10^{5}}{p}\right)$

Molecular diffusivity data for specific model species in air at STP was compiled from Massman (1998) and Yaws et al. (1995) and a temperature and pressure correction similar to that used in Eq. (10) is applied.

The temperature correction function, $f(T)$, is defined as

$f(T)=\frac{T-T_{\min }}{T_{\mathrm{opt}}-T_{\min }}\left[\frac{T_{\mathrm{max}}-T}{T_{\mathrm{max}}-T_{\mathrm{opt}}}\right]^{\frac{T_{\max }-T_{\mathrm{opt}}}{T_{\mathrm{opt}}-T_{\min }}}$

with $T_{\min }=0{ }^{\circ} \mathrm{C}, T_{\max }=45^{\circ} \mathrm{C}$, and $T_{\mathrm{opt}}=27^{\circ} \mathrm{C}$. The water vapor pressure deficit correction, $f(\mathrm{VPD})$, is defined by

$f(\mathrm{VPD})=1-b_{\mathrm{vpd}} \mathrm{VPD}$

$\mathrm{VPD}=e^{\mathrm{sat}}(T)-e$

where, $b_{\mathrm{vpd}}$ is a canopy specific empirical constant $\left(\mathrm{kPa}^{-1}\right)$; VPD is the vapor pressure deficit $(\mathrm{kPa}) ; e^{\text {sat }}(T)$ is the saturation water vapor pressure at air temperature $T(\mathrm{kPa})$; and, $e$ is the ambient water vapor pressure $(\mathrm{kPa})$. A $b_{\mathrm{vpd}}$ value of $0.1 \mathrm{kPa}^{-1}$ as recommended by Wolfe and Thornton (2011) was adopted in this work. The saturation water vapor pressure is computed with the function of Wagner and Pruss (1993).

Finally, the water stress correction function, $f(\psi)$, is defined by

$f(\psi)=\frac{\psi-\psi_{c_{2}}}{\psi_{c_{1}}-\psi_{c_{2}}}$ 
$\psi=-0.72-0.0013 E$

where, $\psi$ is the leaf water potential (MPa); $E$ is the solar irradiance $\left(\mathrm{W} \mathrm{m}^{-2}\right)$, and $\psi_{c_{1}}$ and $\psi_{c_{2}}$ are empirical constants with values $-1.9 \mathrm{MPa}$ and $-2.5 \mathrm{MPa}$, respectively.

For the leaf boundary layer resistance, $r_{\mathrm{b}}$, the formulation of Wu et al. (2003) is used

$r_{\mathrm{b}}=2 \frac{S c^{0.667}}{\kappa u^{*}}$

where, $S c$ is the Schmidt number $=v_{\text {air }} / \mathcal{D}, \kappa$ is von Karman's constant $(=0.4), u^{*}$ is friction velocity, and $v_{\text {air }}$ is the kinematic viscosity of air. Using the analysis of Weber (1999), the friction velocity is approximated as

$u^{*}=0.14 \bar{u}$

where $\bar{u}$ is the mean wind speed $\left(\mathrm{cm} \mathrm{s}^{-1}\right)$, so that the final expression for $r_{\mathrm{b}}$ becomes

$r_{\mathrm{b}}=\frac{10.5}{\mathcal{D}^{0.667} \bar{u}}$

Wesely's (1989) formulation for the mesophyll and cuticular resistances are used

$r_{\mathrm{m}}=\frac{1}{H^{*} / 3000+100 f_{0}}$

$r_{\mathrm{c}}=\frac{r_{\mathrm{c}}^{\mathrm{O}_{3}}}{H^{*} / 10^{5}+f_{0}}$

where, $H^{*}$ is the deposited species effective Henry's Law constant $\left(\mathrm{M} \mathrm{atm}^{-1}\right), f_{0}$ is a species dependent reactivity factor, and $r_{\mathrm{c}} \mathrm{O}_{3}$ is the cuticular resistance for ozone $\left(\mathrm{O}_{3}\right)$, for which Wesely (1989) recommends a value of $20 \mathrm{~s} \mathrm{~cm}^{-1}$ for a deciduous forest. Effective Henry's Law constants were compiled from Zhang et al. (2002), Sander et al. (2011), and Sander (2009). In ACCESS, dry deposition is implemented for all integrated species; however, since physical data is limited or non-existent for many intermediate species of the MCM, default values for $\mathcal{D}\left(0.1 \mathrm{~cm}^{2} \mathrm{~s}^{-1}\right), H^{*}(\ll$ $\left.1 \mathrm{Matm}^{-1}\right)$, and $f_{0}(0.0)$ are used where no reliable data could be obtained.

With the species specific deposition velocities calculated from Eq. (8), the deposition rate to the canopy, $D_{i}$, is then computed as potentially bi-directional with

$D_{i}(z)=-v_{\mathrm{d}_{i}}(z)\left(C_{i}(z)-\Gamma_{i}\right) \operatorname{LAD}(z)$

where, $\Gamma_{i}$ is the compensation point for species $i$ and LAD is the leaf area density function within the canopy $\left(\mathrm{cm}^{2}\right.$ leaf $\left.\mathrm{cm}^{-3}\right)$. Although canopy exchange is implemented in ACCESS as in Eq. (18), compensation points are zero for all species in the simulations reported in this work so that all exchange is uni-directional (i.e., deposition only).

\subsection{Vertical transport}

Vertical exchange between forest canopies and the atmosphere is dominated by turbulent mixing (Finnegan, 2000). For some time it has been recognized that traditional gradient diffusion theory to model turbulent transport within vegetative canopies has substantial limitations (Legg and Monteith, 1975; Shaw, 1977; Raupach and Thom, 1981; Denmead and Bradley, 1985; Baldocchi and Meyers, 1988). In particular, the presence of counter-gradient transport and coherent eddies with length scales approaching $h_{\mathrm{c}}$ have been assessed to be major drivers of the total exchange between forests and atmosphere (Raupach et al., 1996; Finnegan et al., 2009; Steiner et al., 2011; Dupont and Patton, 2012). Attempts have been made to better approximate canopy turbulence with higher-order closure approaches (Wilson and Shaw, 1977; Meyers and Paw U, 1986; Katul and Albertson, 1998), with Lagrangian approaches (Rapauch, 1989a, b), and more recently with large-eddy simulation approaches (Edburg, 2009; Bohrer et al., 2009; Finnegan et al., 2009; Edburg et al., 2012). To a greater or lesser extent, all of these attempts improve the representation of momentum, heat or scalar vertical fluxes within the canopy as compared to measurements over that achievable by a simple first-order closure approach. However, when attempting to model the complex, nonlinear atmospheric chemistry of scalars occurring within and above the canopy, these admittedly more accurate approaches to representing vertical transport become computationally prohibitive. Most previous efforts to simulate forest canopy atmospheric chemistry and vertical transport have thus chosen to represent canopy turbulence with first-order closure K-theory, with a few (Makar et al., 1999; Stroud et al., 2005; Wolfe and Thornton, 2011; Bryan et al., 2012) employing the parameterized eddy diffusivities with Raupach's (1989a) localized-near-field approximation, and even fewer attempting higher-order closure approaches (Gao and Wesely, 1994; Boy et al., 2011). In practice, with currently available computational resources, a compromise must be made between the representation of turbulence and the representation and completeness of the chemical transformations included in the model. Assessments of the overall impact that this compromise may have on the results obtained from canopy chemistry models are limited (Gao and Wesely, 1994; Dlugi et al., 2010). However, the recent work of Steiner et al. (2011) for measurements made during the 2009 CABINEX study demonstrate that intermittent coherent structures (i.e., canopy-scale "sweep-ejection" cycles), which are not adequately modeled by K-theory, may account for a large fraction of momentum (40-50\%) and heat (44-65\%) exchange between the canopy and the lower atmosphere. If the 2009 CABINEX results are representative, then at least half of all heat and momentum transport from forest canopies cannot be modeled adequately with K-theory. However, the assumption is made here that some substantial portion of forest-atmosphere exchange can be reasonably modeled by 
K-theory (or some modification of it) and that insights gained from this approach will be useful to better understand the role of forests in atmospheric chemistry and SOA formation. Future versions of ACCESS may explore this important question further, but in the work reported here a more complete representation of the chemistry is used while a simplified vertical turbulence representation is employed, as described below.

Using Reynolds turbulent decomposition and averaging, the vertical turbulent flux is given by

$$
F_{i}(z)=\overline{w^{\prime} C_{i}^{\prime}}(z)
$$

where, $w^{\prime}$ is the vertical velocity fluctuation, $C_{i}^{\prime}$ is the trace species concentration fluctuation, and the overbar represents time averaging. With a first-order closure assumption of gradient diffusion theory, the vertical turbulent flux is approximated with

$\overline{w^{\prime} C_{i}^{\prime}}(z)=-K_{v}(z) \frac{\partial C_{i}(z)}{\partial z}$

which then gives

$$
\frac{\partial F_{i}(z)}{\partial z}=-\frac{\partial}{\partial z}\left(K_{v}(z) \frac{\partial C_{i}(z)}{\partial z}\right)
$$

for the rate of vertical turbulent mixing. Integrated in the model as a time-split process, the vertical transport is then represented as

$$
\frac{\partial C_{i}(z)}{\partial t}=\frac{\partial}{\partial z}\left(K_{v}(z) \frac{\partial C_{i}(z)}{\partial z}\right)
$$

with boundary conditions

$$
-K_{v}(0) \frac{\partial C_{i}(0)}{\partial z}=-v_{\mathrm{s}_{i}}\left(C_{i}(0)-C_{i}^{\mathrm{s}}\right) \text { at } z=0
$$

and

$$
-K_{v}(h) \frac{\partial C_{i}(h)}{\partial z}=k_{\mathrm{e}}\left(C_{i}(h)-C_{i}^{\mathrm{a}}\right) \text { at } z=h
$$

where, $v_{\mathrm{s}_{i}}$ is the deposition velocity of species $i$ to the forest floor $\left(\mathrm{cm} \mathrm{s}^{-1}\right)$ computed as recommended by Wesely (1989); $C_{i}^{\mathrm{s}}$ is the compensation point concentration of species $i$ in the forest floor soil (molecules $\mathrm{cm}^{-3}$ ), set equal to zero for all species in the work reported here; $k_{\mathrm{e}}$ is the entrainment rate of air above the top of the PBL $\left(\mathrm{cm} \mathrm{s}^{-1}\right)$, chosen to be $100 \mathrm{~cm} \mathrm{~s}^{-1}$ for this work (top model layer turnover time of 2-3 min); $C_{i}^{\mathrm{a}}$ is the concentration of species $i$ above the top of the PBL (molecules $\mathrm{cm}^{-3}$ ); and, $h$ is the height of the PBL (cm).

Eddy diffusivities, $K_{v}$, within the canopy are computed with the localized near-field approximation of Raupach (1989a)

$$
K_{v}(z)=R \sigma_{w}^{2}(z) T_{\mathrm{L}}(z)
$$

where, $\sigma_{w}$ is the standard deviation of the vertical velocity fluctuation $\left(\mathrm{cm} \mathrm{s}^{-1}\right) ; T_{\mathrm{L}}$ is a Lagrangian integral time scale (s); and, $R$ is the near-field correction factor, defined by

$R=\frac{\left(1-e^{-\tau / T_{\mathrm{L}}}\right)\left(\frac{\tau}{T_{\mathrm{L}}}-1\right)^{3 / 2}}{\left(\frac{\tau}{T_{\mathrm{L}}}-1+e^{-\tau / T_{\mathrm{L}}}\right)^{3 / 2}}$

Raupach (1989a) suggests the use of

$T_{\mathrm{L}}=\frac{0.3 h_{\mathrm{c}}}{u^{*}}$

to determine the Lagrangian time scale and Raupach (1989a) and Baldocchi (1997) propose

$\sigma_{w}=u^{*}\left(\alpha_{0}+\left(\alpha_{1}-\alpha_{0}\right) \frac{z}{h_{\mathrm{c}}}\right)$

as a parameterization of the vertical velocity standard deviation, where $\alpha_{0}$ and $\alpha_{1}$ are empirical constants.

In the PBL above the canopy, the parameterization of Ulke (2000) is used

$K_{v}(z)=0.4 u^{*} h\left(\frac{z}{h}\right)\left(1-\frac{z}{h}\right) g\left(z, \frac{h}{L}\right)$

where $L$ is the Obukohv length and $g$ is a function of atmospheric stability,

$g=\left(1+6.9 \frac{h}{L} \frac{z}{h}\right)^{-1}$ for stable conditions, $\frac{h}{L}>0$

$g=\left(1-22 \frac{h}{L} \frac{z}{h}\right)^{1 / 4}$ for unstable conditions, $\frac{h}{L}<0$

$$
g=1 \quad \text { for neutral conditions, } \frac{h}{L}=0
$$

At canopy top, the Ulke (2000) and Raupach (1989a) eddy diffusivities are matched by adjusting the value of $\alpha_{1}$ as a function of $h / L$ (with $\alpha_{0}=0.45, \alpha_{1}$ ranges over $0.5-2.0$ as a function of atmospheric stability).

\subsection{Background mixing}

ACCESS includes an optional process to account for the influence of background sources of trace species on chemistry within and above the canopy. Mixing from these background sources is represented by

$$
A_{i}(z)=-k_{\mathrm{b}}\left(C_{i}(z)-C_{i}^{\mathrm{b}}\right)
$$

where, $k_{\mathrm{b}}$ is an adjustable mixing rate $\left(\mathrm{s}^{-1}\right)$ and $C_{i}^{\mathrm{b}}$ are prescribed background trace species concentrations. This process is configured so that it can be applied to either all integrated species or to only a selected subset. When applied to 
all species, it simulates a true advective mixing process of air from an upwind source, but when applied to only a selected subset of species, it acts to constrain the selected species to tend towards the prescribed values. In this way, simulations can be run where species measured in a field campaign can be constrained to observed values or the background values of certain selected species can be varied to investigate their impact on chemical processes within the canopy. For the simulations reported here, a subset of $\mathrm{CH}_{4}, \mathrm{CO}$ and $\mathrm{O}_{3}$ were prescribed at 1700, 150 and $60 \mathrm{ppbv}$, respectively, with a mixing rate time constant of $\sim 3 \mathrm{~h}$. Additionally, in the experiments presented in section $4.0, \mathrm{NO}_{\mathrm{x}}$ background values were prescribed across a range of $0.1-30 \mathrm{ppbv}$ to investigate the impact of anthropogenic $\mathrm{NO}_{\mathrm{x}}$ sources on canopy biogenic hydrocarbon fluxes.

\section{Application to an isoprene-emission-dominated deciduous forest}

The Walker Branch Watershed (WBW) is a dedicated ecosystem research area on the US Department of Energy's Oak Ridge Reservation in east Tennessee. The 97.5 ha watershed has been the site of long-term ecosystem and atmospheric research activities since the mid-1960's. A flux tower located within the watershed $\left(35^{\circ} 57^{\prime} 30^{\prime \prime} \mathrm{N}, 84^{\circ} 17^{\prime} 15^{\prime \prime} \mathrm{W}\right.$; $365 \mathrm{~m}$ above mean sea level) and $10 \mathrm{~km}$ southwest of Oak Ridge, Tennessee, has served as a focal point for previous atmospheric turbulence and chemical flux measurements (Baldocchi et al., 1984, 1995, 1999; Harley et al., 1997; Fuentes et al., 2007) and the canopy morphology of the forest surrounding the flux tower has been extensively documented (Hutchison et al., 1986; Baldocchi and Hutchison, 1986; Baldocchi et al., 2002). The forest is mixed deciduous consisting of chestnut oak (Quercus prinus), tulip poplar (Liriodendron tulipifera), white oak (Quercus alba), red oak (Quercus rubra), red maple (Acer rubrum), and various hickory species (Carya sp.) in order of decreasing biomass density (Kardol et al., 2010). Confirmation that this site represents an isoprene-emission-dominated canopy was provided by Fuentes et al. (2007), who noted that $\alpha$-pinene and $d$-limonene concentration measurements performed at WBW in July 1999 were two to three orders of magnitude lower than those obtained for isoprene. Since different tree species have differing basal isoprene emission rates (Geron et al., 2001), the effective leaf-level isoprene emission rate, $E_{\mathrm{b}}^{\text {isop }}$, is dependent on the composition and prevalence of tree species and their biomass density in the forest canopy being simulated. In this study, a value of $E_{\mathrm{b}}^{\text {isop }}$ was chosen to be consistent with canopy-scale isoprene fluxes measured at the WBW flux tower. At the time of isoprene flux measurements made at the tower (Baldocchi et al., 1995, 1999; Fuentes et al., 2007), the stand was approximately $50 \mathrm{yr}$ old, the overstory canopy height $\left(h_{\mathrm{c}}\right)$ was $24 \mathrm{~m}$, and the whole canopy leaf area index (LAI) was $4.9 \mathrm{~m}^{2}$ leaf $\mathrm{m}^{-2}$ ground area. In this

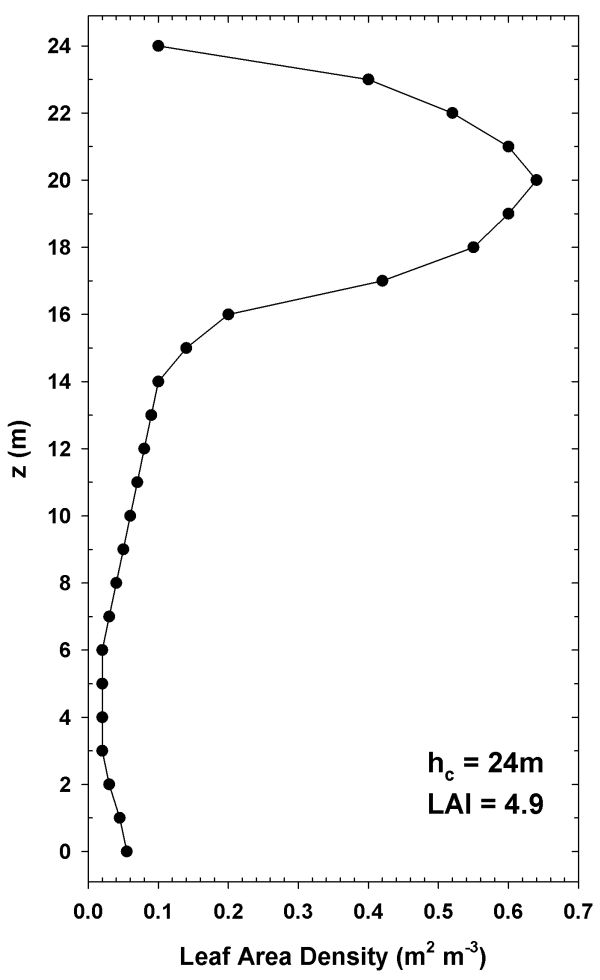

Fig. 1. Profile of leaf area density (LAD, $\mathrm{m}^{2}$ leaf $\mathrm{m}^{-3}$ ground) for Walker Branch Watershed canopy, adapted from Hutchison et al. (1986).

work, ACCESS was applied to the WBW forest to investigate the influence of background anthropogenic $\mathrm{NO}_{\mathrm{x}}$ sources on above canopy fluxes of SOA precursors in an isopreneemission-dominated landscape. The modeled leaf area density (LAD) function of the canopy (idealized from the measurements of Hutchison et al., 1986) is shown in Fig. 1.

Although ACCESS has been designed to ingest meteorological and radiative flux data from a variety of sources, including vertically resolved land surface models or canopy environment models, in this work a combination of climatological data and empirical parameterizations were used to generate input data for the WBW forest application (Figs. 2 and 3). ACCESS was run in steady-state mode, simulating 02:00 p.m. LT on 10 July, with a surface temperature of $303 \mathrm{~K}$ with a vertical profile determined by a $6.5 \mathrm{~K} \mathrm{~km}^{-1}$ lapse rate, surface pressure of $970 \mathrm{mb}$ (geopotential pressure corresponding to $365 \mathrm{~m}$ a.s.l.), and $60 \%$ relative humidity. Above canopy solar insolation, $E_{0}$, was computed for clear sky conditions from the empirical formulation of Meyers and Dale (1983) and canopy top PPFD was then approximated as $0.49 E_{0}$ and converted to $\mu$ mol photons $\mathrm{m}^{-2} \mathrm{~s}^{-1}$. Attenuation of PPFD or actinic flux within the forest canopy is formulated as

$I(z)=I_{0} \cdot \exp \left(-\eta \mathrm{LAI}_{\sum}(z)\right)$ 

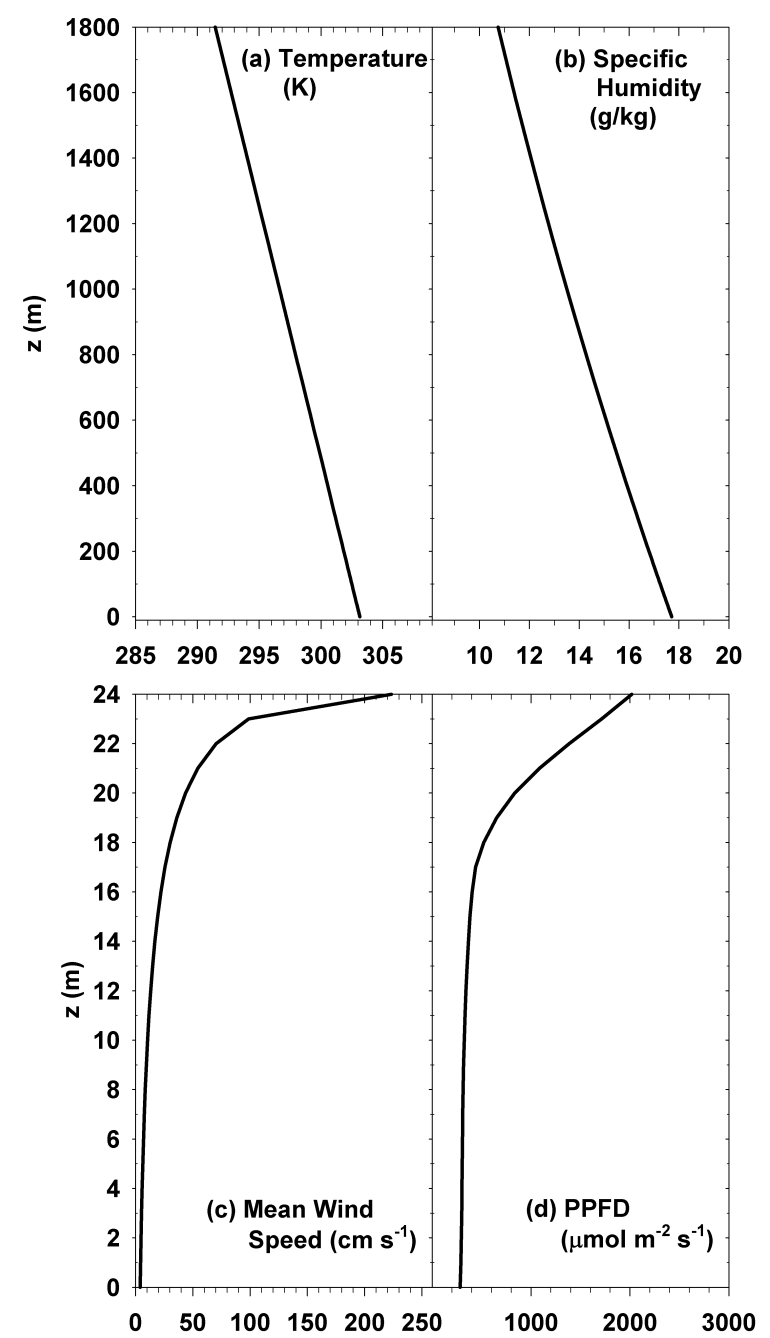

Fig. 2. Input meteorological and radiative flux data used in the Walker Branch Watershed forest canopy simulations for midJuly, 02:00 p.m. LT: (a) air temperature (K); (b) specific humidity $\left(\mathrm{g} \mathrm{kg}^{-1}\right)$; (c) mean wind speed $\left(\mathrm{cm} \mathrm{s}^{-1}\right)$; and, (d) photosynthetic photon flux density ( $\mu$ mol photons $\mathrm{m}^{-2} \mathrm{~s}^{-1}$ ).

where, $\eta$ is the canopy attenuation function for WBW forest as described by Baldocchi and Hutchison (1986) and $\mathrm{LAI}_{\Sigma}$ is the top-down cumulative leaf area index $\left(\mathrm{m}^{2} \mathrm{~m}^{-2}\right)$ of the canopy computed from the leaf area density profile. Finally, the mean wind speed within the canopy, $\bar{u}(z)$, is computed from the empirical relation of Meyers et al. (1998)

$\bar{u}(z)=\bar{u}\left(h_{\mathrm{c}}\right) \exp \left(-\gamma\left(1-z / h_{\mathrm{c}}\right)^{\beta}\right)$

where, $\bar{u}\left(h_{\mathrm{c}}\right)$ is the mean wind speed at canopy top, $\gamma$ is the whole canopy LAI (with a maximum value of 4 ), and $\beta$ is a canopy specific empirical parameter that is set equal to 0.5 for typical deciduous forests.

\section{Results and discussion}

The gas phase oxidation of monoterpenes and sesquiterpenes was originally thought to be the only pathway that produced significant amounts of biogenically derived SOA. However, many studies have suggested recently that additional pathways exist for SOA formation, including gas-phase isoprene reactions (Claeys et al., 2004; Kroll et al., 2006) and aqueous-phase processing of soluble oxidation products of both isoprene and terpenes (Hallquist et al., 2009; Ervens et al., 2008; Lim et al., 2010). In the SE US, isoprene emissions dominate biogenic hydrocarbon sources, accounting for more than 80 percent of total BVOC emissions (Goldstein et al., 2009). Organic matter (OM) comprises roughly 30-40 percent of total fine particle mass in the SE US (Edgerton et al., 2005; Tanner and Parkhurst, 2000) and evidence has accumulated that isoprene oxidation products are routinely found in $\mathrm{PM}_{2.5}$ samples from this region (Clements and Seinfeld, 2007; Edney et al., 2005). Furthermore, ${ }^{14} \mathrm{C}$ isotope studies have indicated that the majority of organic matter in fine particles over the entire US originates from modern sources rather than fossil ones (Schichtel et al., 2008) and this is true in the SE US as well (Tanner et al., 2004; Ding et al., 2008b; Lee et al., 2010). As a whole, this evidence strongly suggests that SOA formed from biogenic isoprene emissions contributes significantly to total fine particle OM in the SE US.

However, as summarized by Lee et al. (2010), there is substantial evidence of a strong anthropogenic influence on OM concentrations in the SE US, in particular for measurements of water-soluble organic carbon (WSOC) in $\mathrm{PM}_{2.5}$ (Weber et al., 2007; Sullivan and Weber, 2006; Zhang et al., 2012), which exhibit strong correlations with anthropogenic pollutants such as CO, elemental carbon and fossil fuel hydrocarbons. On the other hand, Ding et al. (2008a) observed significant correlations of WSOC from $\mathrm{PM}_{2.5}$ samples in the SE US with the isoprene oxidation products 2-methyltetrols. Weber et al. (2007) speculate that some anthropogenic component (or components) influences the amount of SOA formed, regardless of whether the VOC is biogenic or anthropogenic in origin. In a comprehensive review article, Hoyle et al. (2011) survey the currently known possible mechanisms through which anthropogenic sources may enhance the formation of biogenic SOA. In this work, ACCESS is applied to an isoprene-emission-dominated forest canopy to investigate the relative magnitude of SOA precursor concentrations and fluxes above the canopy as a function of background levels of $\mathrm{NO}_{\mathrm{x}}$. Assuming that higher levels of background $\mathrm{NO}_{\mathrm{x}}$ are associated with anthropogenic sources, the results of these simulations may suggest one mechanism by which higher levels of biogenic SOA can be directly correlated with anthropogenic influences.

Details of the mechanism of isoprene oxidation are still the subject of vigorous investigation (Stone et al., 2011; Archibald et al., 2010a, b; Galloway et al., 2011). In 


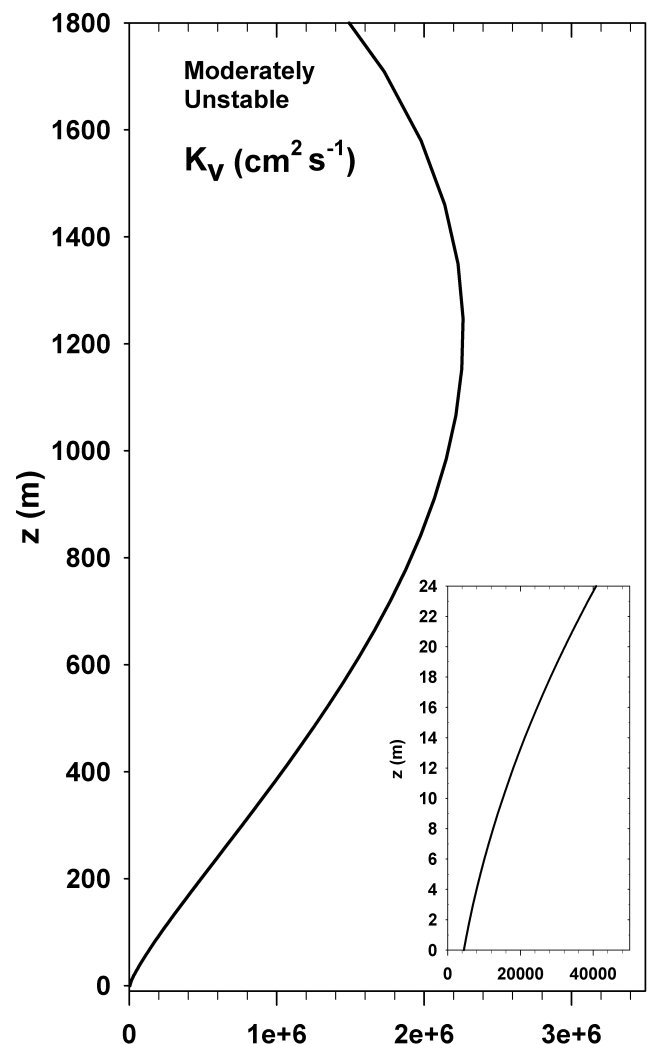

Fig. 3. Eddy diffusivity profile (moderately unstable, $h / L=-10$ ) used in the Walker Branch Watershed forest canopy simulation for mid-July, 02:00 p.m. LT $\left(\mathrm{cm}^{2} \mathrm{~s}^{-1}\right)$. Inset presents $K_{v}$ profile within the canopy.

particular, knowledge of the intricacies of $\mathrm{HO}_{\mathrm{x}}$ chemistry in low $\mathrm{NO}_{\mathrm{x}}$, high isoprene environments is advancing rapidly (Lelieveld et al., 2008; Hofzumahaus et al., 2009; Paulot et al., 2009; Crounse et al., 2011; Peeters and Müller, 2010; Pugh et al., 2010; Wolfe et al., 2012), but remains uncertain. Since $\mathrm{NO}_{\mathrm{x}}$ mixing ratios within the WBW canopy are typically in the 2-6 ppbv range (Fuentes et al., 2007), the uncertainties in the mechanism of isoprene in low $\mathrm{NO}_{\mathrm{x}}$ environments ( $\ll 1 \mathrm{ppbv})$ should not introduce excessive errors in the results presented here. Carlton et al. (2009) reviewed understanding as of 2008 of the reaction pathways that may lead to SOA formation from isoprene. First-generation products methacrolein and methyl vinyl ketone (MVK) are the best characterized and evidence indicates that reactions involving methacrolein likely lead to SOA formation while MVK reaction products do not. Under low $\mathrm{NO}_{\mathrm{x}}$ conditions, first-generation organic peroxides are more prevalent (Surratt et al., 2006), but as already mentioned there is substantial mechanistic uncertainty in this regime. Considerable interest has recently been focused on several small, second-generation products including glyoxal, glycolaldehyde, methyl glyoxal and hydroxyacetone. Absorption and chemical processing of these water-soluble compounds in

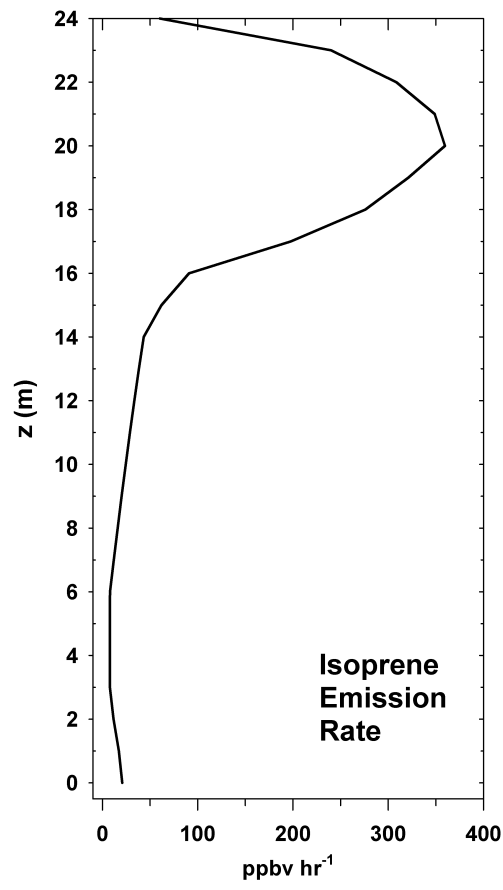

Fig. 4. Isoprene emission rate profile used in the Walker Branch Watershed forest canopy simulation for mid-July, 02:00 p.m. LT $\left(\mathrm{ppbvh}^{-1}\right)$.

cloud droplets or wet aerosols are suspected to add to total SOA mass via aqueous oligomerization reactions (Lim et al., 2005; Ervens et al., 2008; Altieri et al., 2006, 2008; Carlton et al., 2007; Ortiz-Montalvo et al., 2012). Recent global-scale simulations including aqueous-phase SOA production have indicated that these pathways account for a substantial fraction of total SOA produced in the global atmosphere (Liu et al., 2012; Lin et al., 2012). In the simulations reported below, the concentration profiles and fluxes of methacrolein, MVK, glyoxal, methyl glyoxal, glycolaldehyde and hydroxyacetone are examined as a function of background $\mathrm{NO}_{\mathrm{x}}$ levels.

For each experiment of the simulated WBW canopy, a fixed concentration of $\mathrm{NO}_{\mathrm{x}}(0.1,1.0,5,10$ and $30 \mathrm{ppbv})$ was specified for a well-mixed background boundary layer that was mixed into the column with a $\sim 3 \mathrm{~h}$ mixing time constant (Wolfe and Thornton, 2011). Each simulation was run with fixed vertical profiles of all meteorological (Figs. 2 and 3) and isoprene emissions data (Fig. 4) and a fixed solar zenith angle corresponding to 02:00 p.m. LT at the WBW latitude and longitude. Initial conditions, background concentrations and free tropospheric concentrations were identical for each simulation as specified in Table 1 . The simulations were each run for a total of $12 \mathrm{~h}$ which allowed ample time for a steady state to be achieved for all species, as shown in Fig. 5 for $\mathrm{NO}_{2}$ and isoprene. All results shown below use profiles from $t=12 \mathrm{~h}$ as the steady-state result. Figure 6 presents the steady-state profiles of $\mathrm{NO}_{2}$ and $\mathrm{O}_{3}$ which resulted for each specified background $\mathrm{NO}_{\mathrm{x}}\left(\mathrm{bNO}_{\mathrm{x}}\right)$ value. 
Table 1. Specified Initial, Background and Above PBL Mixing Ratios for Walker Branch Watershed Simulations.

\begin{tabular}{ll}
\hline & Initial \\
\hline Species & Value \\
\hline $\mathrm{O}_{3}$ & $60 \mathrm{ppbv}$ \\
$\mathrm{CO}$ & $150 \mathrm{ppbv}$ \\
$\mathrm{CH}$ & $1700 \mathrm{ppbv}$ \\
$\mathrm{OH}$ & $1 \times 10^{6}$ molecules cm $^{-3}$ \\
$\mathrm{HO}_{2}$ & $1 \times 10^{8}$ molecules cm $^{-3}$ \\
All other species & 0 ppbv \\
\hline
\end{tabular}

\begin{tabular}{ll}
\hline & Background \\
\hline Species & Value \\
\hline $\mathrm{O}_{3}$ & $60 \mathrm{ppbv}$ \\
$\mathrm{CO}$ & $150 \mathrm{ppbv}$ \\
$\mathrm{CH}_{4}$ & $1700 \mathrm{ppbv}$ \\
$\mathrm{NO}_{\mathrm{x}}$ & $0.1,1,5,10,30 \mathrm{ppbv}$ \\
\hline
\end{tabular}

Above PBL

\begin{tabular}{ll}
\hline Species & Value \\
\hline $\mathrm{O}_{3}$ & $60 \mathrm{ppbv}$ \\
$\mathrm{CO}$ & $150 \mathrm{ppbv}$ \\
$\mathrm{CH}_{4}$ & $1700 \mathrm{ppbv}$ \\
$\mathrm{All}$ other species & $0 \mathrm{ppbv}$ \\
\hline
\end{tabular}

\subsection{Isoprene profiles and fluxes}

Simulated vertical profiles of isoprene as a function of background $\mathrm{NO}_{\mathrm{x}}$ value are presented in Fig. 7. Profiles over the full model domain (Fig. 7a) exhibit a relatively rapid monotonic decrease with height as is expected for a near surface emitted species that is chemically reactive. Increasing $\mathrm{bNO}_{\mathrm{x}}$ values increase the reactivity of the system by increasing steady-state values of ozone and hydroxyl radical concentrations and thus increasing the rates of chemical loss of isoprene, thereby decreasing the steady-state values of isoprene throughout the modeled column. Modeled isoprene mixing ratios in and just above the canopy (Fig. 7b) are seen to agree relatively well with measurements (means \pm 1 standard deviation) made by Baldocchi et al. (1995) and Fuentes et al. (2007) at the WBW flux tower. Since $\mathrm{NO}_{\mathrm{x}}$ mixing ratios measured by Fuentes et al. (2007) at WBW ranged from 2 to $6 \mathrm{ppbv}$, this falls between the $\mathrm{bNO}_{\mathrm{x}}=5 \mathrm{ppbv}$ and $\mathrm{bNO}_{\mathrm{x}}=30$ ppbv experiments (see Fig. 6). The isoprene measurements of Fuentes et al. (2007) are thus somewhat larger in the upper canopy than model results but are comparable otherwise. The modeled near-surface mixing ratios and vertical profiles also compare qualitatively with other profile measurements made in or near the SE US. Andronache et al. (1994) analyzed vertical profiles of isoprene from balloon-borne measurements made in western Alabama during July 1990 and found means of 37 profiles which ranged from $>4 \mathrm{ppbv}$ at the surface and dropped quickly to less than 2 ppbv by $300 \mathrm{~m}$ above ground level (a.g.l.). They categorized the profiles into two groups roughly equal in number, "simple" profiles in which the mixing ratio decreased monotonically with height and "complex" profiles where a maximum occurred somewhere above the surface. The "complex" profiles were characterized by non-uniform turbulence structures with layers of strong wind shear or enhanced vertical stability. Wiedinmyer et al. (2005) presented surface and balloon-borne isoprene measurements made in and near the Ozarks in central Missouri as part of the Ozarks Isoprene Experiment in July 1998. Ground-level isoprene mixing ratios ranged from $<1$ to $35 \mathrm{ppbv}$ in the oak dominated (similar to WBW) forests of the Ozarks and balloon-measured means of afternoon mixing ratios ranged from 3-4 ppbv near $200 \mathrm{~m}$ a.g.l. to $<2$ ppbv just above $800 \mathrm{~m}$ a.g.l.

Modeled vertical fluxes of isoprene (Fig. 8a) peak near 50-70 m, whereas the maximum chemical loss of isoprene (Fig. 8b) occurs just above the canopy top $(\sim 30 \mathrm{~m})$ where maximum photochemical activity occurs. Modeled isoprene fluxes compare reasonably well with the measurements of Baldocchi et al. (1995) at WBW, but are generally somewhat smaller than those measured by Fuentes et al. (2007). As seen in Fig. 8, as $\mathrm{bNO}_{\mathrm{x}}$ increases over the simulated range, peak chemical loss rates of isoprene increase from $<2 \mathrm{ppbvh}^{-1}$ to almost $15 \mathrm{ppbvh}^{-1}$ just above canopy top, while the maximum isoprene flux decreases from $>26$ to near $20 \mathrm{nmol} \mathrm{m}^{-2} \mathrm{~s}^{-1}$ (a decrease of $>20 \%$ ). Maximum modeled isoprene fluxes at or just above canopy top were also observed by Gao et al. (1993) and Doskey and Gao (1999). Stroud et al. (2005) examined the impact of anthropogenic pollution on the overall canopy fluxes of isoprene and only found a small change (a maximum $4 \%$ decrease) between scenarios ranging from clean continental to urban. Results from other canopy modeling efforts have varied widely in assessing the impact that chemical loss has on isoprene fluxes from the canopy. Using the same base model as Stroud et al. (2005), Makar et al. (1999) estimated that neglecting chemistry would result in substantially $(\sim 40 \%)$ larger isoprene mixing ratios above the canopy. On the other hand, Gao et al. (1993) and Doskey and Gao (1999) both estimated only negligible impact of chemical loss on above canopy isoprene fluxes, while Forkel et al. (2006) reported a 10 $15 \%$ reduction in isoprene fluxes due to chemistry. Because these studies use various condensed chemical mechanisms and have attempted to simulate different forest canopy morphologies and species across a broad range of BVOC emission rates and background chemical concentrations, it is difficult to draw definitive conclusions. Reconciling these disparate results will require a more complete investigation into the environmental, biological and anthropogenic factors that may influence the role that chemistry plays in above canopy isoprene fluxes. Because of the ongoing uncertainties in isoprene chemistry in low $\mathrm{NO}_{\mathrm{x}}$ environments, model results presented here at the lowest $\mathrm{bNO}_{\mathrm{x}}$ levels are also uncertain 

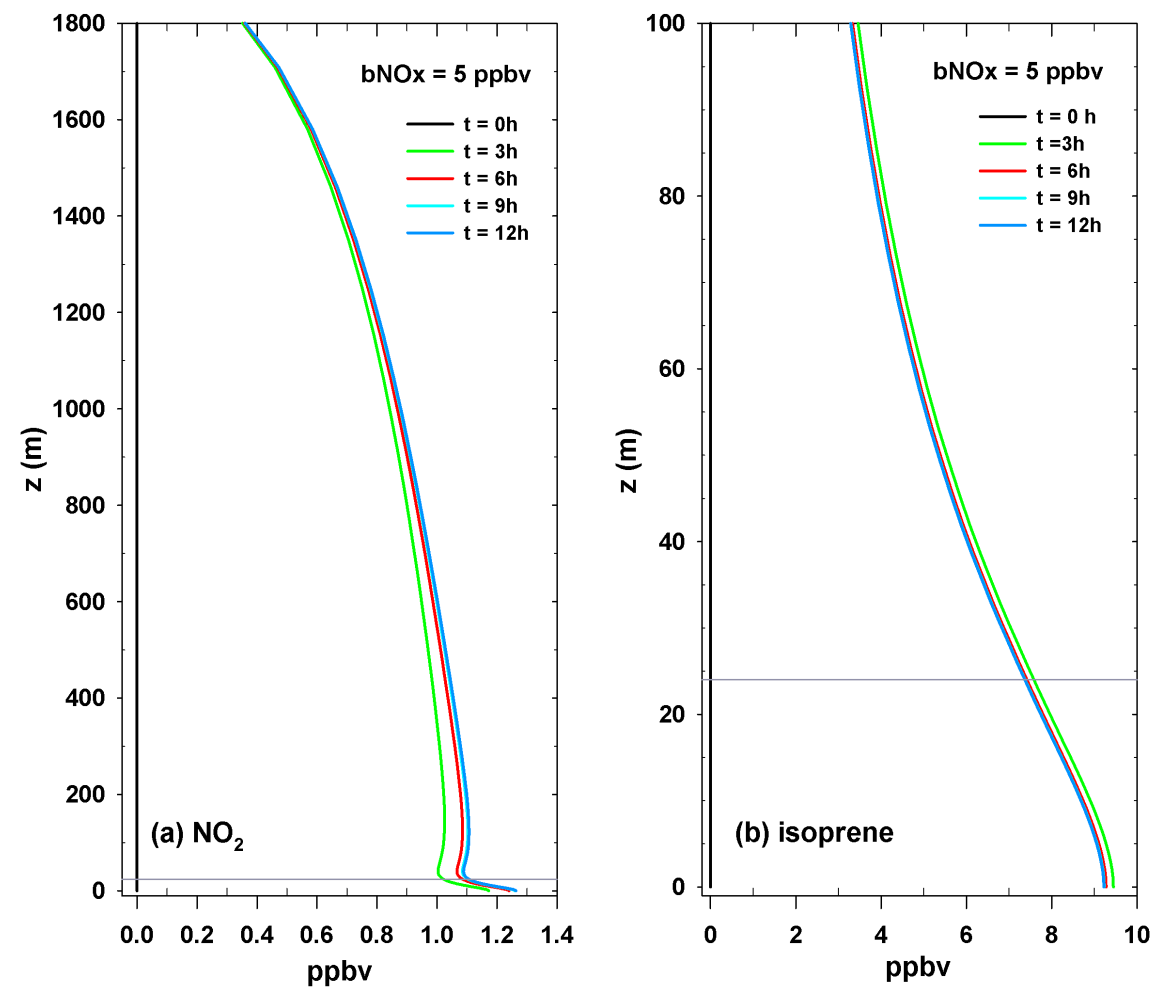

Fig. 5. Vertical profiles of (a) $\mathrm{NO}_{2}$ and (b) isoprene for $\mathrm{bNO}_{\mathrm{x}}=5 \mathrm{ppbv}$, illustrating the approach to steady-state over the $12 \mathrm{~h}$ simulation (horizontal gray line is canopy top height).
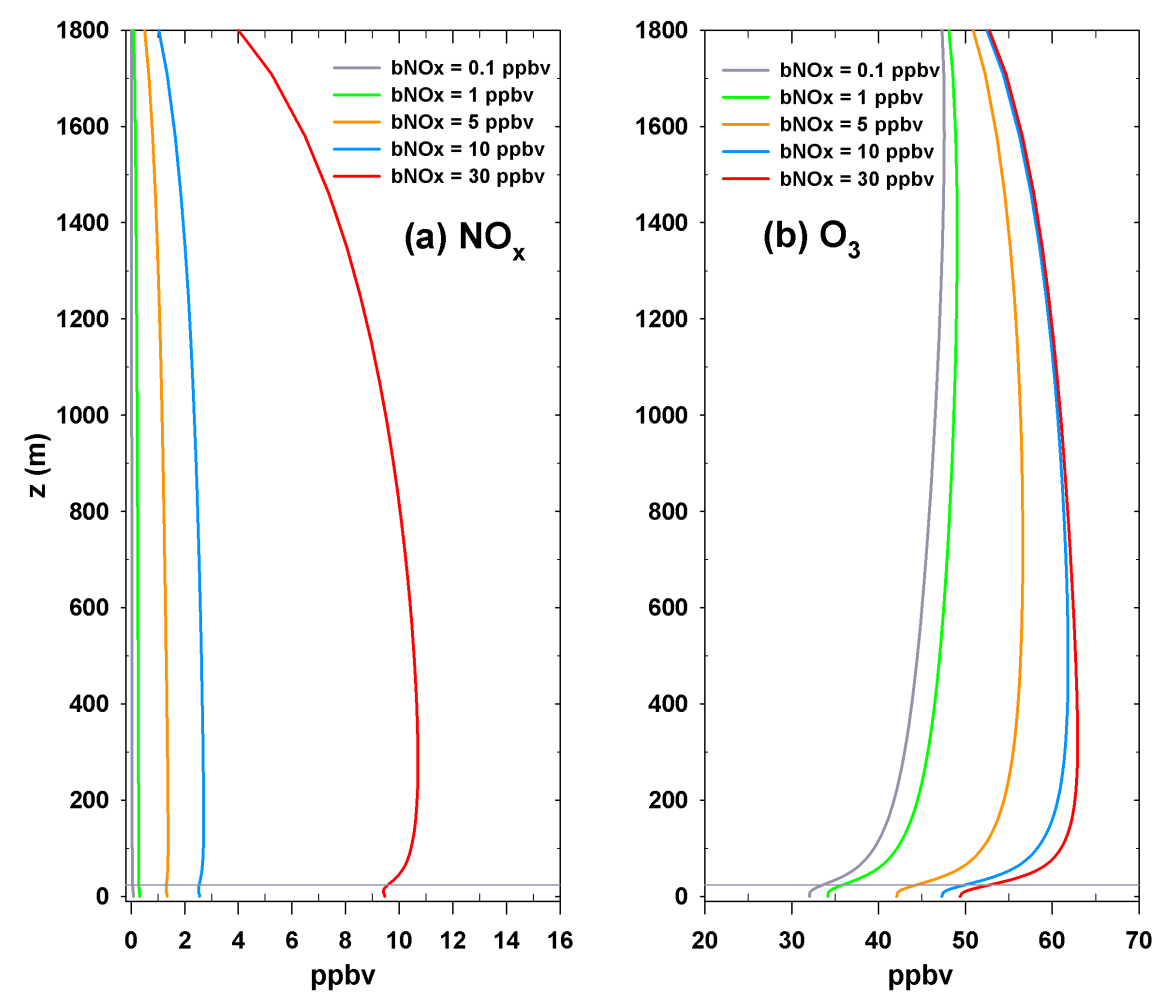

Fig. 6. Steady-state vertical profiles of (a) $\mathrm{NO}_{\mathrm{x}}$ and (b) $\mathrm{O}_{3}$ for each background $\mathrm{NO}_{\mathrm{x}}$ value (horizontal gray line is canopy top height). 

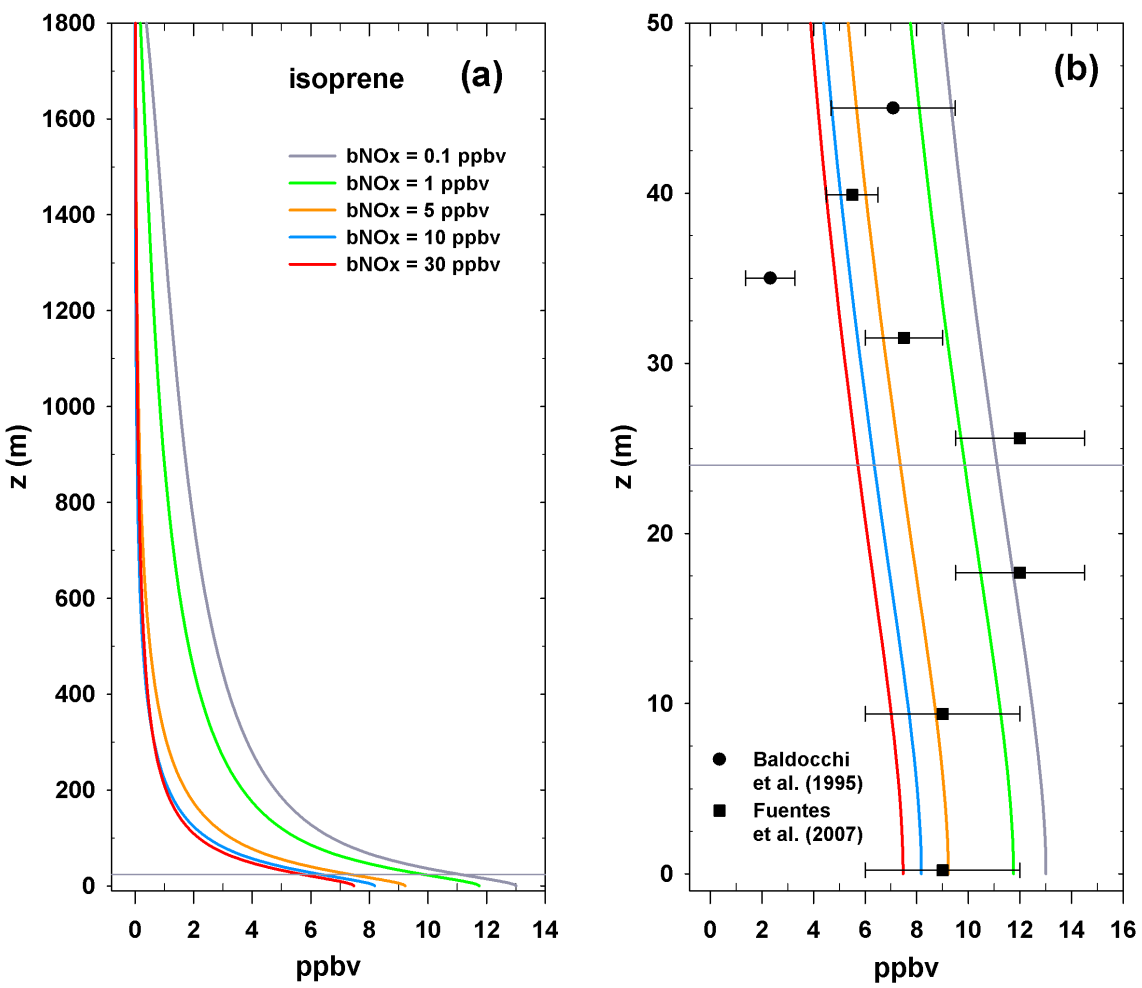

Fig. 7. Steady-state vertical profiles of isoprene (ppbv) for each background $\mathrm{NO}_{\mathrm{x}}$ value for (a) the entire column and for (b) the lowest $50 \mathrm{~m}$ with measurements (means \pm 1 standard deviation) of Baldocchi et al. (1995) and Fuentes et al. (2007) (horizontal gray line is canopy top height).

and will need to be revisited in future studies as details of the chemistry in this regime become clearer.

Fuentes et al. (2007) presented data from one day (20 July) at WBW showing that isoprene measurements peaked in the upper levels of the canopy, however model results from ACCESS exhibit a gradual decrease of isoprene from the surface upwards, which is typical for a relatively well-mixed vertical column. To obtain peaks in isoprene at canopy top that are $30 \%$ larger than values obtained at or near the surface as shown by Fuentes et al. (2007) may imply only very slight vertical mixing when these measurements were taken, since it would not be expected that chemical loss of isoprene would be stronger deeper within the shaded canopy. However, since Fuentes et al. (2007) do not provide details concerning in-canopy turbulence or atmospheric stability (other than modeled canopy residence times) on the day of these measurements, it is difficult to assess this supposition. As mentioned earlier, it has been recognized for some time that within canopy turbulence is complex; several recent studies (Steiner et al., 2011; Bryan et al., 2012; Dupont and Patton, 2012) have re-emphasized the importance of simultaneous measurement of turbulent mixing parameters when performing chemical profile measurements in and above forest canopies. The frequency of occurrence (roughly half of the total measurements) of the "complex" vertical profiles of An- dronache et al. (1994) also emphasizes the importance of detailed characterization of the atmospheric turbulence structure within and above the canopy for a full understanding of chemically reactive exchanges between the biosphere and atmosphere.

\subsection{Isoprene oxidation products}

Simulated mixing ratio profiles, vertical fluxes and chemical production/loss rates are presented as a function of $\mathrm{bNO}_{\mathrm{x}}$ for first- and second-generation products of isoprene oxidation in Figs. 9-14. The first generation products methacrolein (Fig. 9) and MVK (Fig. 10) exhibit similar profiles, with MVK concentrations and fluxes generally being larger (roughly $2 \times$ ) for a given $\mathrm{bNO}_{\mathrm{x}}$ value. The peaks of chemical production of methacrolein and MVK coincide with the maximum chemical loss of isoprene just above canopy top $(\sim 30 \mathrm{~m})$ and the magnitude of chemical production increases with increasing $\mathrm{bNO}_{\mathrm{x}}$ value. Higher in the boundary layer, the net chemical budget for these species changes from production to loss as conversion to secondgeneration products becomes more dominant than production from isoprene. The height above canopy top where this transition from net production to net loss occurs decreases with increasing $\mathrm{bNO}_{\mathrm{x}}$ value, as does the height of maximum vertical flux. 

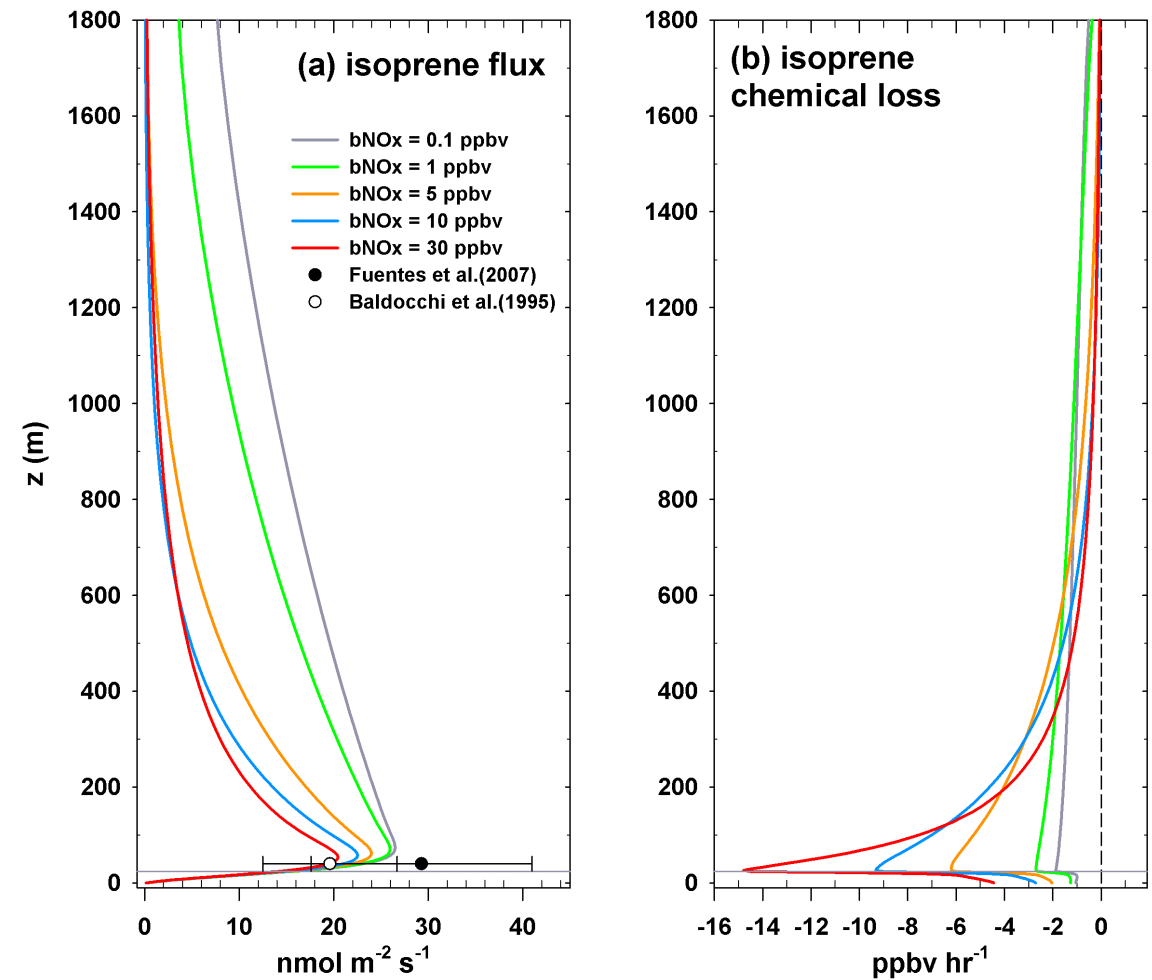

Fig. 8. Steady-state profiles of (a) isoprene vertical flux $\left(\mathrm{nmol} \mathrm{m}^{-2} \mathrm{~s}^{-1}\right)$ and (b) isoprene chemical loss $\left(\mathrm{ppbv} \mathrm{h}^{-1}\right)$ for each background $\mathrm{NO}_{\mathrm{x}}$ value (horizontal gray line is canopy top height). Measured isoprene flux data (means \pm 1 standard deviation) from Baldocchi et al. (1995) and Fuentes et al. (2007) for Walker Branch Watershed.

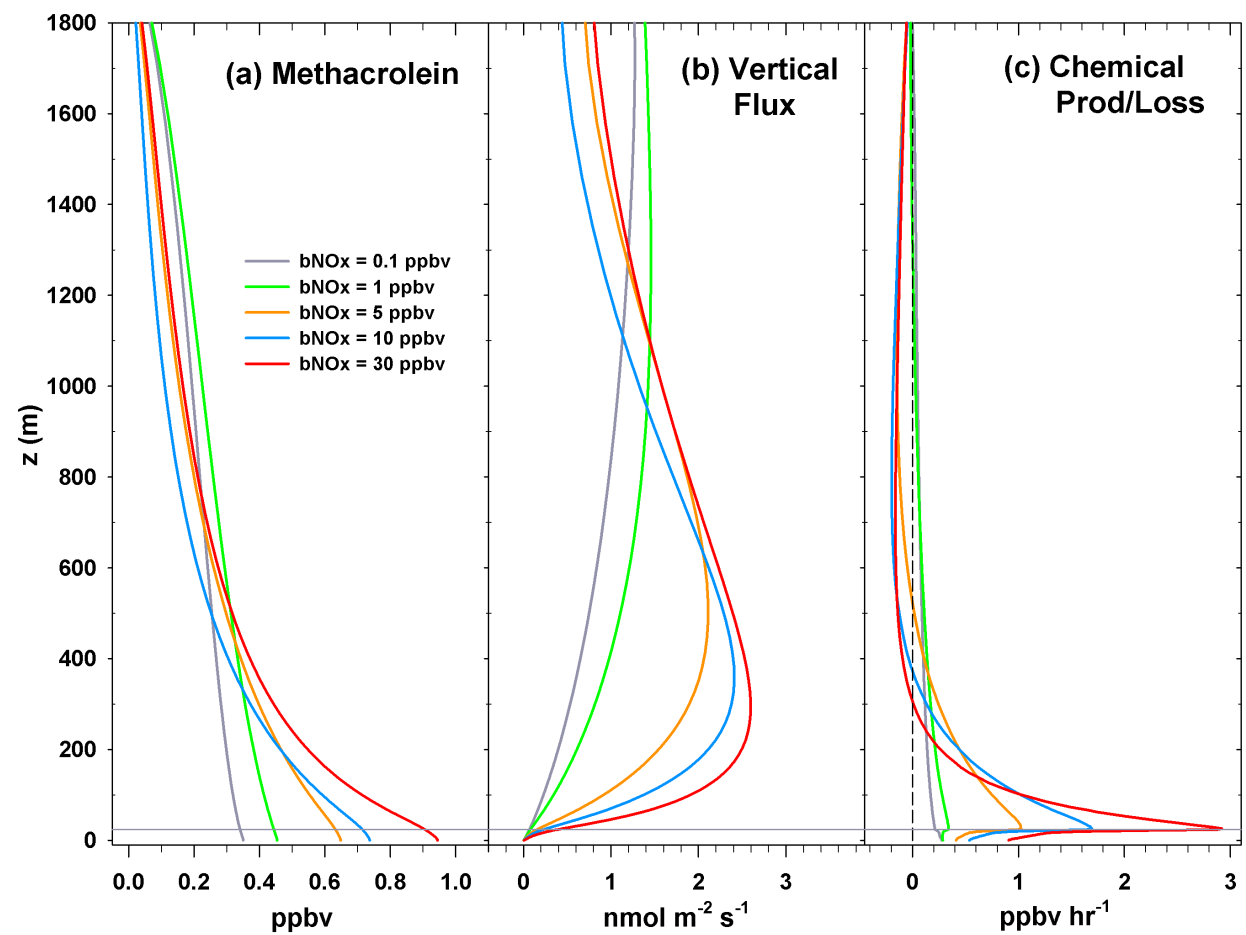

Fig. 9. Vertical profiles of methacrolein (a) mixing ratio (ppbv), (b) vertical flux $\left(n m o l m^{-2} \mathrm{~s}^{-1}\right.$ ), and (c) chemical production or loss $\left(\mathrm{ppbv} \mathrm{h}^{-1}\right.$ ) for each background $\mathrm{NO}_{\mathrm{x}}$ value (horizontal gray line is canopy top height). 


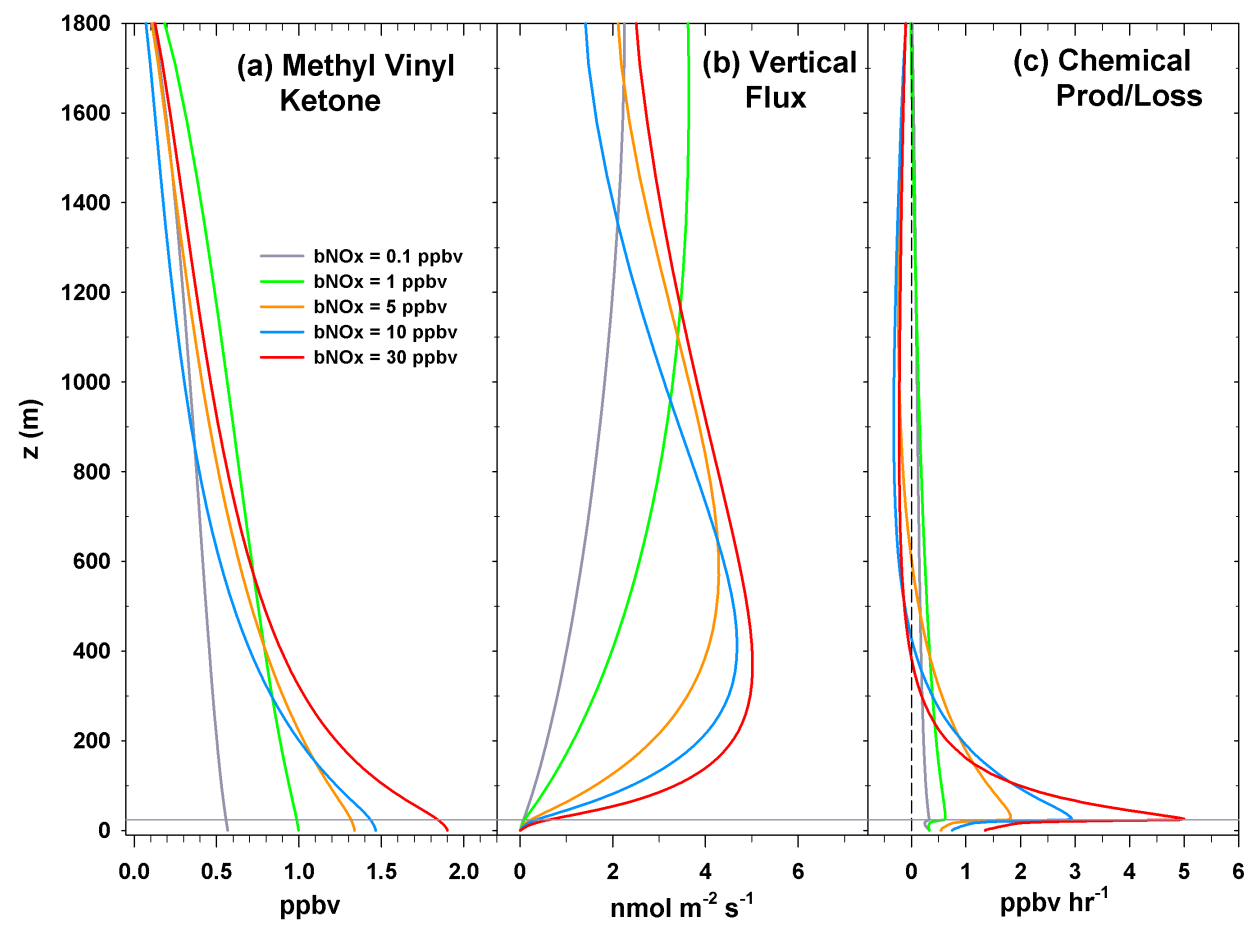

Fig. 10. Vertical profiles of MVK (a) mixing ratio (ppbv), (b) vertical flux (nmol m${ }^{-2} \mathrm{~s}^{-1}$ ), and (c) chemical production or loss (ppbv $\mathrm{h}^{-1}$ ) for each background $\mathrm{NO}_{\mathrm{x}}$ value (horizontal gray line is canopy top height).

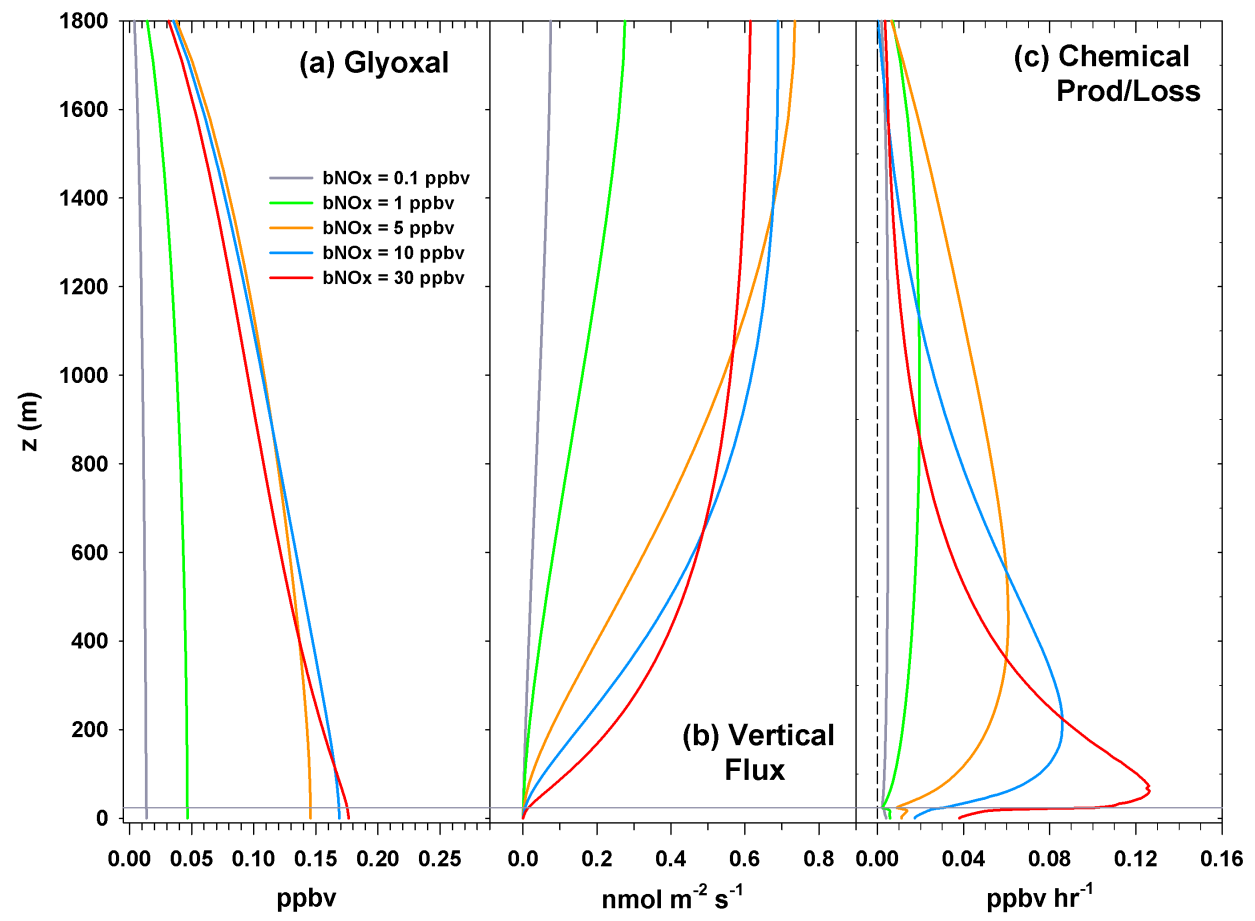

Fig. 11. Vertical profiles of glyoxal (a) mixing ratio (ppbv), (b) vertical flux (nmol m${ }^{-2} \mathrm{~s}^{-1}$ ), and (c) chemical production or loss (ppbv $\mathrm{h}^{-1}$ ) for each background $\mathrm{NO}_{\mathrm{x}}$ value (horizontal gray line is canopy top height). 


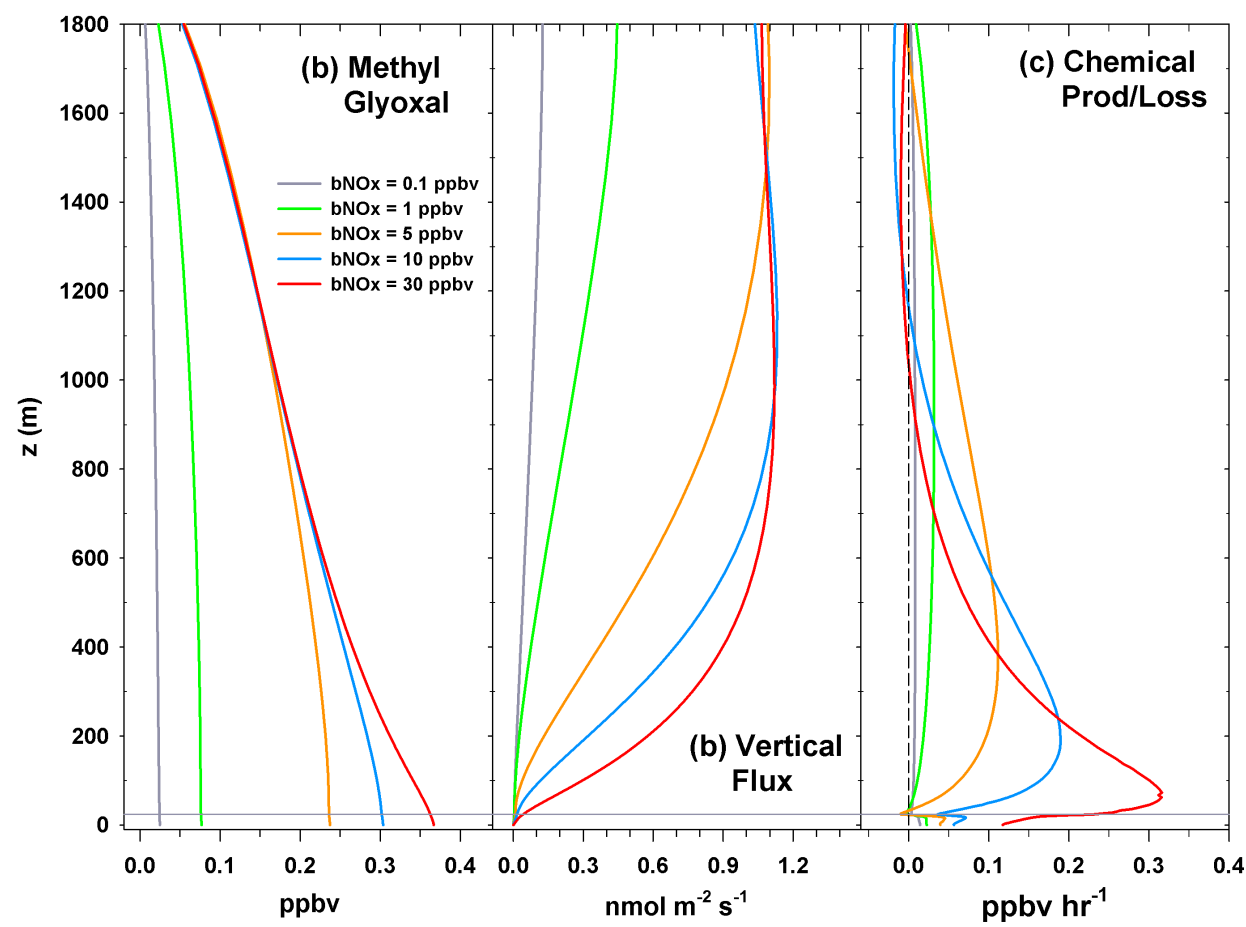

Fig. 12. Vertical profiles of methyl glyoxal (a) mixing ratio (ppbv), (b) vertical flux (nmol m $\mathrm{m}^{-2} \mathrm{~s}^{-1}$ ), and (c) chemical production or loss $\left(\mathrm{ppbv} \mathrm{h}^{-1}\right.$ ) for each background $\mathrm{NO}_{\mathrm{x}}$ value (horizontal gray line is canopy top height).

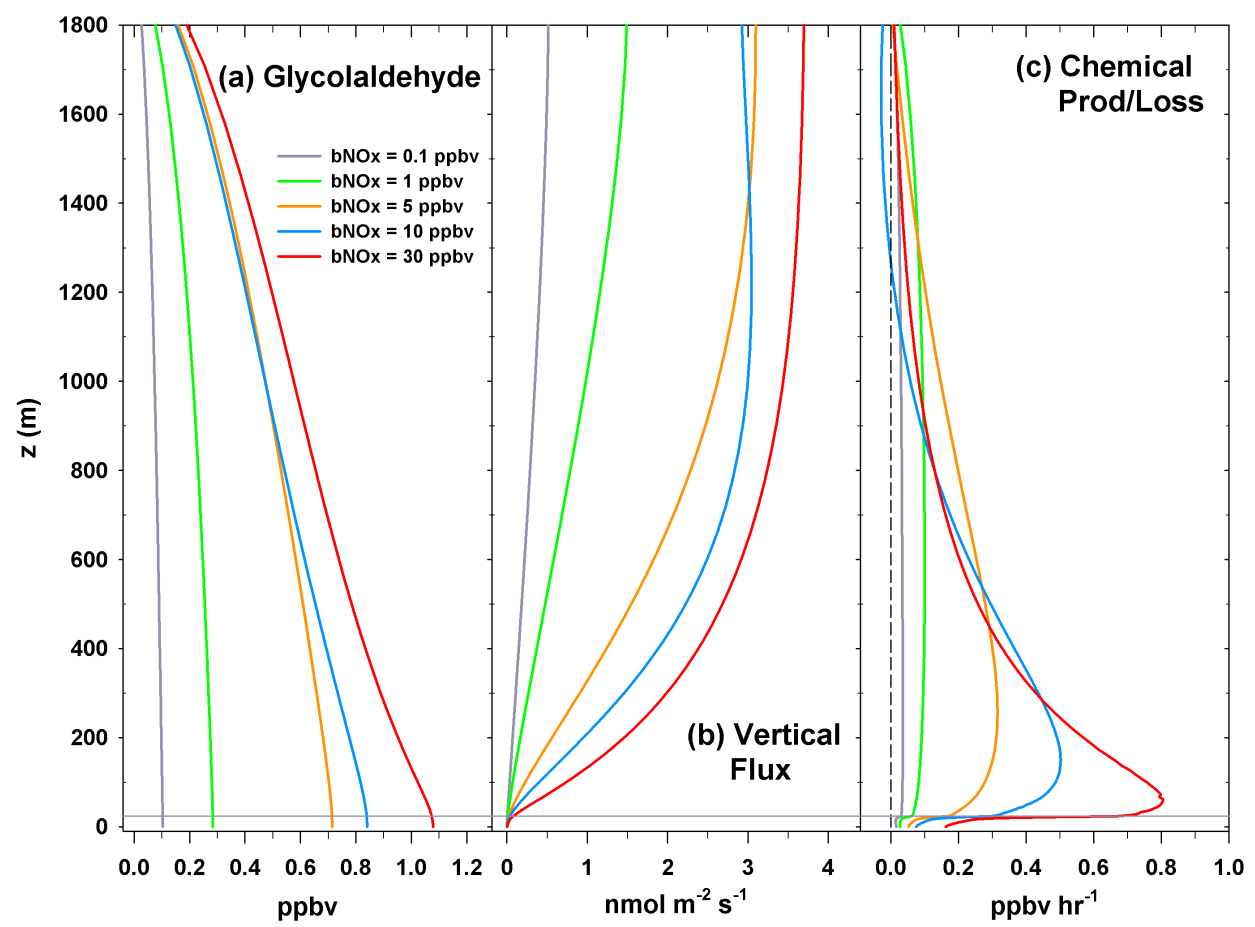

Fig. 13. Vertical profiles of glycolaldehyde (a) mixing ratio (ppbv), (b) vertical flux (nmol m${ }^{-2} \mathrm{~s}^{-1}$ ), and (c) chemical production or loss $\left(\mathrm{ppbv} \mathrm{h}^{-1}\right.$ ) for each background $\mathrm{NO}_{\mathrm{x}}$ value (horizontal gray line is canopy top height). 


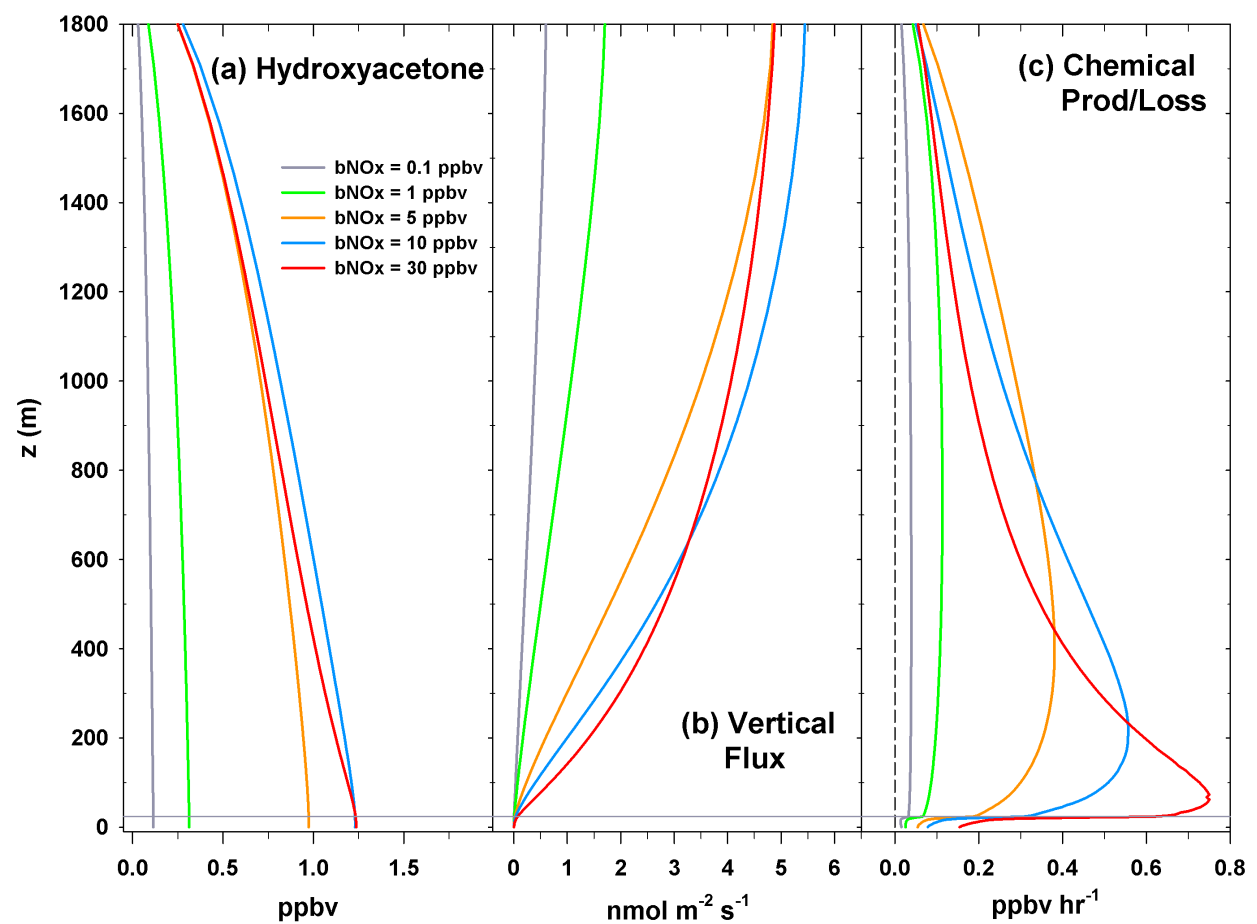

Fig. 14. Vertical profiles of hydroxyacetone (a) mixing ratio (ppbv), (b) vertical flux (nmol m $\mathrm{m}^{-2} \mathrm{~s}^{-1}$ ), and (c) chemical production or loss $\left(\mathrm{ppbvh}^{-1}\right.$ ) for each background $\mathrm{NO}_{\mathrm{x}}$ value (horizontal gray line is canopy top height).

Table 2. Mean Within-Canopy Mixing Ratios (ppbv) for Selected Isoprene Oxidation Products as a Function of Background $\mathrm{NO}_{\mathrm{x}}$ and Simulated $\mathrm{NO}_{\mathrm{x}}$.

\begin{tabular}{llllllll}
\hline $\mathrm{bNO}_{\mathrm{x}}$ & $\mathrm{NO}_{\mathrm{x}}$ & methacrolein & $\mathrm{MVK}$ & glyoxal & methyl glyoxal & glycolaldehyde & hydroxyacetone \\
\hline $0.1 \mathrm{ppbv}$ & 0.07 & 0.34 & 0.56 & 0.014 & 0.024 & 0.10 & 0.11 \\
$1.0 \mathrm{ppbv}$ & 0.3 & 0.45 & 0.99 & 0.047 & 0.077 & 0.28 & 0.31 \\
$5.0 \mathrm{ppbv}$ & 1.3 & 0.64 & 1.3 & 0.15 & 0.24 & 0.71 & 0.97 \\
$10 \mathrm{ppbv}$ & 2.5 & 0.72 & 1.4 & 0.17 & 0.30 & 0.84 & 1.2 \\
$30 \mathrm{ppbv}$ & 9.5 & 0.92 & 1.9 & 0.18 & 0.37 & 1.1 & 1.2 \\
\hline
\end{tabular}

The second-generation products glyoxal (Fig. 11), methyl glyoxal (Fig. 12), glycolaldehyde (Fig. 13), and hydroxyacetone (Fig. 14) exhibit vertical profiles and variations with $\mathrm{bNO}_{\mathrm{x}}$ that are similar to each other but different from methacrolein and MVK. Mixing ratio vertical profiles of the second-generation products do not drop off in magnitude with height as quickly as with methacrolein and MVK and vertical flux profiles generally continue to increase throughout the depth of the boundary layer for all values of $\mathrm{bNO}_{\mathrm{x}}$. Additionally, the vertical profile of the chemical production rate of second-generation products changes significantly with increasing $\mathrm{bNO}_{\mathrm{x}}$ and the height at which the peak rate occurs lowers with increasing $b_{N O}$ values. It is notable that the magnitudes of the vertical profiles of these species do not necessarily increase monotonically with increases in $\mathrm{bNO}_{\mathrm{x}}$ value but exhibit inherent non-linearities. For example, the glyoxal mixing ra- tio for $\mathrm{bNO}_{\mathrm{x}}=30 \mathrm{ppbv}$ is larger near the surface than the value at $\mathrm{bNO}_{\mathrm{x}}=10 \mathrm{ppbv}$, but eventually decreases below the profiles for both $\mathrm{bNO}_{\mathrm{x}}=10 \mathrm{ppbv}$ and $\mathrm{bNO}_{\mathrm{x}}=5 \mathrm{ppbv}$ above $400 \mathrm{~m}$. Similarly, the vertical profiles (and fluxes) of methyl glyoxal, glycolaldehyde and hydroxyacetone exhibit non-linear variations with $\mathrm{bNO}_{\mathrm{x}}$ that are non-intuitive, reflecting a complex interaction between vertical transport and chemistry. For second-generation products shown in Figs. 11-14, the relative magnitude of within canopy mean mixing ratios (Table 2) is sequenced as hydroxyacetone $>$ glycoaldehyde $>$ methyl glyoxal $>$ glyoxal for all values of simulated $\mathrm{bNO}_{\mathrm{x}}$. Interestingly, although methacrolein and MVK concentrations increase approximately 3-fold from the lowest to highest values of $\mathrm{bNO}_{\mathrm{x}}$, the secondgeneration products exhibit increases ranging from 11-fold (glycolaldehyde - from 0.1 to $1.1 \mathrm{ppbv}$ ) to 15 -fold (methyl glyoxal - from 0.024 to $0.37 \mathrm{ppbv}$ ). Although not explicitly 
investigated in this initial study, these non-linearities of firstand second-generation products with respect to photochemical activity (via background $\mathrm{NO}_{\mathrm{x}}$ levels) may have important implications for the potential production of SOA through aqueous-phase versus gas-phase pathways. Using a parcel model with aqueous-phase SOA formation chemistry, Ervens et al. (2008) found that the yield of SOA mass increased with increasing $\mathrm{NO}_{\mathrm{x}}$ levels (or alternatively, with decreasing $\mathrm{VOC} / \mathrm{NO}_{\mathrm{x}}$ values). Non-linearities such as that found in Ervens et al. (2008) and suggested in this work may not be captured well by coarser-resolution regional- or global-scale models. Future work will further explore the broader implications of these findings.

\section{Summary and future applications}

Many scientific questions and uncertainties remain concerning the formation of SOA in the atmosphere. Emissions of BVOCs from vegetative canopies, and from forests in particular, and the chemical transformations and turbulent vertical mixing that occurs within and above the canopy play an important role in the formation pathways of SOA. In this work a new modeling system designed to investigate these pathways has been described in detail and results from an initial application of a gas-phase-only version of the model to an isoprene-dominated deciduous forest canopy in the SE US has been presented. The model produces reasonable withincanopy isoprene concentrations as compared to measurements made during two summer field measurement studies at the simulated site and with other measurements of vertical mixing ratio profiles of isoprene in or near the SE US. Preliminary analyses of the mixing ratio profiles and vertical fluxes of first- and second-generation isoprene oxidation products as a function of background $\mathrm{NO}_{\mathrm{x}}$ levels exhibit nonlinearities that may have important implications for the pathways through which SOA is formed in different oxidative environments and will be the focus of near-term follow on studies of this work.

Future applications of the current ACCESS modeling system will include explorations of the environmental and anthropogenic factors which control mixing ratio profiles and vertical fluxes of SOA precursor species and attempt to identify improved treatments of current BVOC emissions parameterizations for three-dimensional atmospheric chemistry and air quality models to better represent the inherent nonlinearities of the chemistry and physics of atmosphere-forest exchange. Particularly vital in this work will be comparisons and analyses of simulation results with either past or future measurements made in intensive field campaigns in forested environments. Future versions of ACCESS will include multiphase chemistry and transport to more fully investigate and evaluate the aqueous- and aerosol-phase chemical processes that contribute to overall SOA formation in the atmosphere.

\section{Supplementary material related to this article is available online at: http://www.atmos-chem-phys.net/13/ 693/2013/acp-13-693-2013-supplement.zip.}

Acknowledgements. This work has been performed with support from NOAA's Office of Oceanic and Atmospheric Research through the US Weather Research Program. The author thanks Steven Fine, Richard Artz and Bruce Baker for encouragement during the pursuit of this work, Ariel Stein for productive discussions during the development of the modeling system, and two anonymous reviewers whose constructive comments and suggestions significantly improved the final manuscript. The author also sincerely thanks Maggie Robinson at ATDD for her patient and tireless pursuit of numerous journal articles and reports.

Edited by: R. Cohen

\section{References}

Altieri, K. E., Carlton, A. G., Turpin, B. J., and Seitzinger, S.: Formation of oligomers in cloud-processing: Reactions of isoprene oxidation products, Environ. Sci. Technol., 40, 4956-4960, 2006.

Altieri, K. E., Seitzinger, S. P., Carlton, A. G., Turpin, B. J., Klein, G. C., and Marshall, A. G.: Oligomers formed through in-cloud methylglyoxal reactions: chemical composition, properties, and mechanisms investigated by ultra-high resolution FT-ICR mass spectrometry, Atmos. Environ., 42, 1476-1490, 2008.

Andronache, C., Chameides, W. L., Rodgers, M. O., Martinez, J., Zimmerman, P., and Greenberg, J.: Vertical distribution of isoprene in the lower boundary layer of the rural and urban southern United States, J. Geophys. Res., 99, 16989-16999, 1994.

Archibald, A. T., Cooke, M. C., Utembe, S. R., Shallcross, D. E., Derwent, R. G., and Jenkin, M. E.: Impacts of mechanistic changes on $\mathrm{HO}_{\mathrm{x}}$ formation and recycling in the oxidation of isoprene, Atmos. Chem. Phys., 10, 8097-8118, doi:10.5194/acp-108097-2010, 2010a.

Archibald, A. T., Jenkin, M. E., and Shallcross, D. E.: An isoprene mechanism intercomparison, Atmos. Environ., 44, 5356-5364, $2010 b$.

Baldocchi, D.: Flux footprints within and over forest canopies, Bound.-Lay. Meteorol., 85, 273-292, 1997.

Baldocchi, D. and Hutchison, B.: On estimating canopy photosynthesis and stomatal conductance in a deciduous forest with clumped foliage, Tree Physiol., 2, 155-168, 1986.

Baldocchi, D. D. and Meyers, T. P.: Turbulence structure in a deciduous forest, Bound.-Lay. Meteorol., 43, 345-364, 1988.

Baldocchi, D. D., Matt, D. R., Hutchison, B. A., and McMillen, R. T.: Solar radiation within an oak-hickory forest: An evaluation of the extinction coefficients for several radiation components during fully-leafed and leafless periods, Agr. Forest Meteorol., 32, 307-322, 1984.

Baldocchi, D., Guenther, A., Harley, P., Klinger, L., Zimmerman, P., Lamb, B., and Westberg, H.: The fluxes and air chemistry of isoprene above a deciduous hardwood forest, Philos. T. Royal Soc. Lond. A, 350, 279-296, 1995.

Baldocchi, D. D., Fuentes, J. D., Bowling, D. R., Turnipseed, A. A., and Monson, R. K.: Scaling isoprene fluxes from leaves to 
canopies: Test cases over a boreal aspen and a mixed species temperate forest, J. Appl. Meteorol., 38, 885-898, 1999.

Baldocchi, D. D., Wilson, K. B., and Gu, L.: How the environment, canopy structure and canopy physiological functioning influence carbon, water and energy fluxes of a temperate broadleaved deciduous forest - an assessment with the biophysical model CANOAK, Tree Physiol., 22, 1065-1077, 2002.

Bohrer, G., Katul, G. G., Walko, R. L., and Avissar, R.: Exploring the effects of microscale structural heterogeneity of forest canopies using large-eddy simulations, Bound.-Lay. Meteorol., 132, 351-382, 2009.

Boy, M., Sogachev, A., Lauros, J., Zhou, L., Guenther, A., and Smolander, S.: SOSA - a new model to simulate the concentrations of organic vapours and sulphuric acid inside the ABL Part 1: Model description and initial evaluation, Atmos. Chem. Phys., 11, 43-51, doi:10.5194/acp-11-43-2011, 2011.

Brown, P. N., Byrne, G. D., and Hindmarsh, A. C.: VODE: A variable-coefficient ODE solver, SIAM Journal of Scientific and Statistical Computing, 10, 1038-1051, 1989.

Bryan, A. M., Bertman, S. B., Carroll, M. A., Dusanter, S., Edwards, G. D., Forkel, R., Griffith, S., Guenther, A. B., Hansen, R. F., Helmig, D., Jobson, B. T., Keutsch, F. N., Lefer, B. L., Pressley, S. N., Shepson, P. B., Stevens, P. S., and Steiner, A. L.: Incanopy gas-phase chemistry during CABINEX 2009: sensitivity of a 1-D canopy model to vertical mixing and isoprene chemistry, Atmos. Chem. Phys., 12, 8829-8849, doi:10.5194/acp-12-88292012, 2012.

Carlton, A. G., Turpin, B. J., Altieri, K. E., Reff, A., Seitzinger, S., Lim, H. J., and Ervens, B.: Atmospheric oxalic acid and SOA production from glyoxal: Results of aqueous photooxidation experiments, Atmos. Environ., 41, 7588-7602, 2007.

Carlton, A. G., Wiedinmyer, C., and Kroll, J. H.: A review of Secondary Organic Aerosol (SOA) formation from isoprene, Atmos. Chem. Phys., 9, 4987-5005, doi:10.5194/acp-9-4987-2009, 2009.

Carroll, M. A., Bertman, S. B., and Shepson, P. B.: Overview of the Program for Research on Oxidants: Photochemistry, Emissions and Transport (PROPHET) summer 1998 measurements intensive, J. Geophys. Res., 106, 24275-24288, 2001.

Chameides, W. L., Lindsay, R. W., Richardson, J., and Kiang, C. S.: The role of biogenic hydrocarbons in urban photochemical smog: Atlanta as a case study, Science, 241, 1473-1475, 1988.

Claeys, M., Graham, B., Vas, G., Wang, W., Vermeylen, R., Pashynska, V., Cafmeyer, J., Guyon, P., Andreae, M. O., Artaxo, P., and Maenhaut, W.: Formation of secondary organic aerosol through photooxidation of isoprene, Science, 303, 1173-1176, 2004.

Clements, A. L. and Seinfeld, J. H.: Detection and quantification of 2-methyltetrols in ambient aerosol in the southeastern United States, Atmos. Environ., 41, 1825-1830, 2007.

Crounse, J. D., Paulot, F., Kjaergaard, H. G., and Wennberg, P. O.: Peroxy radical isomerization in the oxidation of isoprene, Phys. Chem. Chem. Phys., 13, 13607-13613, 2011.

Denmead, O. T. and Bradley, E. F.: Flux-gradient relationships in a forest canopy, The Forest-Atmosphere Interaction, D. Reidel Publ. Co., Boston, 421-442, 1985.

Ding, X., Zheng, M., Yu, L. Zhang, X., Weber, R. J., Yan, B., Russell, A. G., Edgerton, E. S., and Wang, X.: Spatial and seasonal trends in biogenic secondary organic aerosol tracers and watersoluble organic carbon in the southeastern United States, Envi- ron. Sci. Technol., 42, 5171-5176, 2008 a.

Ding, X., Zheng, M., Edgerton, E. S., Jansen, J. J., and Wang, X.: Contemporary or fossil origin: Split of estimated secondary organic carbon in the southeastern United States, Environ. Sci. Technol., 42, 9122-9128, $2008 \mathrm{~b}$.

Dlugi, R., Berger, M., Zelger, M., Hofzumahaus, A., Siese, M., Holland, F., Wisthaler, A., Grabmer, W., Hansel, A., Koppmann, R., Kramm, G., Möllmann-Coers, M., and Knaps, A.: Turbulent exchange and segregation of $\mathrm{HO}_{\mathrm{x}}$ radicals and volatile organic compounds above a deciduous forest, Atmos. Chem. Phys., 10, 6215-6235, doi:10.5194/acp-10-6215-2010, 2010.

Doskey, P. V. and Gao, W.: Vertical mixing and chemistry of isoprene in the atmospheric boundary layer: Aircraft-based measurements and numerical modeling, J. Geophys. Res., 104, 21263-21274, 1999.

Dupont, S. and Patton, E. G.: Momentum and scalar transport within a vegetation canopy following atmospheric stability and seasonal canopy changes: the CHATS experiment, Atmos. Chem. Phys., 12, 5913-5935, doi:10.5194/acp-12-5913-2012, 2012.

Edburg, S. L.: A Numerical Study of Turbulence, Dispersion, and Chemistry within and Above Forest Canopies, Ph.D. Dissertation, Washington State University, May, 2009.

Edburg, S. L., Stock, D., Lamb, B. K., and Patton, E. G.: The effect of the vertical source distribution on scalar statistics within and above a forest canopy, Bound.-Lay. Meteorol., 142, 365-382, 2012.

Edgerton, E. S., Hartsell, B. E., Saylor, R. D., Jansen, J. J., Hansen, D. A., and Hidy, G. M.: The Southeastern Aerosol Research and Characterization Study: Part II. Filter-based measurements of fine and coarse particulate matter mass and composition, J. Air Waste Manage., 55, 1527-1542, 2005.

Edney, E. O., Kleindienst, T. E., Jaoui, M., Lewandowski, M., Offenberg, J. H., Wang, W., and Claeys, M.: Formation of 2-methyl tetrols and 2-methylglyceric acid in secondary organic aerosol from laboratory irradiated isoprene/ $\mathrm{NO}_{\mathrm{x}} / \mathrm{SO}_{2} /$ air mixtures and their detection in ambient $\mathrm{PM}_{2.5}$ samples collected in the eastern United States, Atmos. Environ., 39, 5281-5289, 2005.

Ervens, B., Carlton, A. G., Turpin, B. J., Altieri, K. E., Kreidenweiss, S. M., and Feingold, G.: Secondary organic aerosol yields from cloud-processing of isoprene oxidation products, Geophys. Res. Lett., 35, L02816, doi:10.1029/2007GL031828, 2008.

Finnigan, J.: Turbulence in plant canopies, Annu. Rev. Fluid Mech., 32, 519-571, 2000.

Finnigan, J. J., Shaw, R. H., and Patton, E. G.: Turbulence structure above a vegetation canopy, J. Fluid Mech., 637, 387-424, 2009.

Forkel, R., Klemm, O., Graus, M., Rappengluck, B., Stockwell, W. R., Grabmer, W., Held, A., Hansel, A., and Steinbrecher, R.: Trace gas exchange and gas phase chemistry in a Norway spruce forest: A study with a coupled 1-dimensional canopy atmospheric chemistry emission model, Atmos. Environ., 40, S28S42, 2006.

Fuentes, J. D., Lerdau, M., Atkinson, R., Baldocchi, D., Bottenheim, J. W., Ciccioli, P., Lamb, B., Geron, C., Gu, L., Guenther, A., Sharkey, T. D., and Stockwell, W.: Biogenic hydrocarbons in the atmospheric boundary layer: A review, B. Am. Meteorol. Soc., 81, 1537-1575, 2000.

Fuentes, J. D., Wang, D., Bowling, D. R., Potosnak, M., Monson, R. K., Goliff, W. S., and Stockwell, W. R.: Biogenic hydrocarbon chemistry within and above a mixed deciduous forest, J. Atmos. 
Chem., 56, 165-185, 2007.

Galloway, M. M., Huisman, A. J., Yee, L. D., Chan, A. W. H., Loza, C. L., Seinfeld, J. H., and Keutsch, F. N.: Yields of oxidized volatile organic compounds during the $\mathrm{OH}$ radical initiated oxidation of isoprene, methyl vinyl ketone, and methacrolein under high- $\mathrm{NO}_{\mathrm{x}}$ conditions, Atmos. Chem. Phys., 11, 10779-10790, doi:10.5194/acp-11-10779-2011, 2011.

Gao, W. and Wesely, M. L.: Numerical modeling of the turbulent fluxes of chemically reactive trace gases in the atmospheric boundary layer, J. Appl. Meteorol., 33, 835-847, 1994.

Gao, W., Wesely, M. L., and Doskey, P. V.: Numerical modeling of the turbulent diffusion and chemistry of $\mathrm{NO}_{\mathrm{x}}, \mathrm{O}_{3}$, isoprene, and other reactive trace gases in and above a forest canopy, $\mathrm{J}$. Geophys. Res., 98, 18339-18353, 1993.

Geron, C., Harley, P., and Guenther, A.: Isoprene emission capacity for US tree species, Atmos. Environ., 35, 3341-3352, 2001.

Goldstein, A. H. and Galbally, I. E.: Known and unexplored organic constituents in the earth's atmosphere, Environ. Sci. Technol., 41, 1514-1521, 2007.

Goldstein, A. H., Hultman, N. E., Fracheboud, J. M., Bauer, M. R., Panek, J. A., Xu, M., Qi, Y., Guenther, A. B., and Baugh, W.: Effects of climate variability on the carbon dioxide, water and sensible heat fluxes above a ponderosa pine plantation in the Sierra Nevada (CA), Agr. Forest Meteorol., 101, 113-129, 2000.

Goldstein, A. H., Koven, C. D., Heald, C. L., and Fung, I. Y.: Biogenic carbon and anthropogenic pollutants combine to form a cooling haze over the southeastern United States, P. Natl. Acad. Sci. USA, 106, 8835-8840, 2009.

Guenther, A. B., Zimmerman, P. R., Harley, P. C., Monson, R. K., and Fall, R.: Isoprene and monoterpene emission rate variability: Model evaluations and sensitivity analyses, J. Geophys. Res., 98, 12609-12617, 1993.

Guenther, A., Hewitt, C. N., Erickson, D., Fall, R., Geron, C., Graedel, T., Harley, P., Klinger, L., Lerdau, M. T., McKay, W. A., Pierce, T., Scholes, B., Steinbrecher, R., Tallamraju, R., Taylor, J., and Zimmerman, P.: A global model of natural volatile organic compound emissions, J. Geophys. Res., 100, 8873-8892, 1995.

Hallquist, M., Wenger, J. C., Baltensperger, U., Rudich, Y., Simpson, D., Claeys, M., Dommen, J., Donahue, N. M., George, C., Goldstein, A. H., Hamilton, J. F., Herrmann, H., Hoffmann, T., Iinuma, Y., Jang, M., Jenkin, M. E., Jimenez, J. L., Kiendler-Scharr, A., Maenhaut, W., McFiggans, G., Mentel, Th. F., Monod, A., Prévôt, A. S. H., Seinfeld, J. H., Surratt, J. D., Szmigielski, R., and Wildt, J.: The formation, properties and impact of secondary organic aerosol: current and emerging issues, Atmos. Chem. Phys., 9, 5155-5236, doi:10.5194/acp-9-51552009, 2009.

Harley, P., Guenther, A., and Zimmerman, P.: Environmental controls over isoprene emission in deciduous oak canopies, Tree Physiol., 17, 705-714, 1997.

Hofzumahaus, A., Rohrer, F., Lu, K., Bohn, B. Brauers, T., Chang, C. C., Fuchs, H., Holland, F., Kita, K., Kondo, Y., Li, X., Lou, S., Shao, M., Zeng, L., Wahner, A., and Zhang, Y.: Amplified trace gas removal in the troposphere, Science, 324, 1702-1704, 2009.

Hoyle, C. R., Boy, M., Donahue, N. M., Fry, J. L., Glasius, M., Guenther, A., Hallar, A. G., Huff Hartz, K., Petters, M. D., Petäjä, T., Rosenoern, T., and Sullivan, A. P.: A review of the anthropogenic influence on biogenic secondary organic aerosol, Atmos. Chem. Phys., 11, 321-343, doi:10.5194/acp-11-321-2011, 2011.
Hutchison, B. A., Matt, D. R., McMillen, R. T., Gross, L. J., Tajchman, S. J., and Norman, J. M.: The architecture of a deciduous forest canopy in eastern Tennessee, USA, J. Ecol., 74, 635-646, 1986.

Kardol, P., Todd, D. E., Hanson, P. J., and Mulholland, P. J.: Longterm successional forest dynamics: species and community responses to climatic variability, J. Veg. Sci., 21, 627-642, 2010.

Karl, T., Harley, P., Guenther, A., Rasmussen, R., Baker, B., Jardine, K., and Nemitz, E.: The bi-directional exchange of oxygenated VOCs between a loblolly pine (Pinus taeda) plantation and the atmosphere, Atmos. Chem. Phys., 5, 3015-3031, doi:10.5194/acp-5-3015-2005, 2005.

Katul, G. G. and Albertson, J. D.: An investigation of higher-order closure models for a forested canopy, Bound.-Lay. Meteorol., 89, 47-74, 1998.

Kim, S., Guenther, A., Karl, T., and Greenberg, J.: Contributions of primary and secondary biogenic VOC to total $\mathrm{OH}$ reactivity during the CABINEX (Community Atmosphere-Biosphere INteractions Experiments)-09 field campaign, Atmos. Chem. Phys., 11, 8613-8623, doi:10.5194/acp-11-8613-2011, 2011.

Klemm, O., Held, A., Forkel, R., Gasche, R., Kanter, H.-J., Rappengluck, B., Steinbrecher, R., Muller, K., Plewka, A., Cojocariu, C., Kreuzwieser, J., Valverde-Canossa, J., Schuster, G., Moortgat, G. K., Graus, M., and Hansel, A.: Experiments on forest/atmosphere exchange: climatology and fluxes during two summer campaigns in NE Bavaria, Atmos. Environ., 40, S3-S20, 2006.

Kroll, J. H., Ng, N. L., Murphy, S. M., Flagan, R. C., and Seinfeld, J. H.: Secondary organic aerosol formation from isoprene photooxidation, Environ. Sci. Technol., 40, 1869-1877, 2006.

Kulmala, M., Haemeri, K. K., Aalto, P., Maekelae, J., Pirjola, L., Nilsson, E. D., Buzorius, G., Rannik, U., Dal Maso, M., Seidl, W., Hoffmann, T., Jansson, R., Hansson, H.-C., O'Dowd, C., and Viisanen, Y.: Overview of the international project on biogenic aerosol formation in the boreal forest (BIOFOR), Tellus B, 53, 324-343, 2001.

Lee, S., Wang, Y., and Russell, A. G.: Assessment of secondary organic carbon in the southeastern United States: A review, J. Air Waste Manage., 60, 1282-1292, 2010.

Legg, B. J. and Monteith, J. L.: Heat and mass transfer in plant canopies, Heat and Mass Transfer in the Biosphere, Wiley and Sons, New York, 167-186, 1975.

Lelieveld, J., Butler, T. M., Crowley, J. N., Dillon, T. J., Fischer, H., Ganzeveld, L., Harder, H., Lawrence, M. G., Martinez, M., Taraborrelli, D., and Williams, J.: Atmospheric oxidation capacity sustained by a tropical forest, Nature, 452, 737-740, 2008.

Lim, H.-J., Carlton, A. G., and Turpin, B. J.: Isoprene forms secondary organic aerosol through cloud processing: model simulations, Environ. Sci. Technol., 39, 4441-4446, 2005.

Lim, Y. B., Tan, Y., Perri, M. J., Seitzinger, S. P., and Turpin, B. J.: Aqueous chemistry and its role in secondary organic aerosol (SOA) formation, Atmos. Chem. Phys., 10, 1052110539, doi:10.5194/acp-10-10521-2010, 2010.

Lin, G., Penner, J. E., Sillman, S., Taraborrelli, D., and Lelieveld, J.: Global modeling of SOA formation from dicarbonyls, epoxides, organic nitrates and peroxides, Atmos. Chem. Phys., 12, 47434774, doi:10.5194/acp-12-4743-2012, 2012.

Liu, J., Horowitz, L. W., Fan, S., Carlton, A. G., and Levy II, H.: Global in-cloud production of secondary organic aerosols: 
Implementation of a detailed chemical mechanism in the GFDL atmospheric model AM3, J. Geophys. Res., 117, D15303, doi:10.1029/2012JD017838, 2012.

Makar, P. A., Fuentes, J. D., Wang, D., Staebler, R. M., and Wiebe, H. A.: Chemical processing of biogenic hydrocarbons within and above a temperate deciduous forest, J. Geophys. Res., 104, 35813603, 1999.

Malhi, Y., Meir, P., and Brown, S.: Forests, carbon and global climate, Philos. T. Roy. Soc. Lond. A, 360, 1567-1591, 2002.

Mao, J., Ren, X., Zhang, L., Van Duin, D. M., Cohen, R. C., Park, J.-H., Goldstein, A. H., Paulot, F., Beaver, M. R., Crounse, J. D., Wennberg, P. O., DiGangi, J. P., Henry, S. B., Keutsch, F. N., Park, C., Schade, G. W., Wolfe, G. M., Thornton, J. A., and Brune, W. H.: Insights into hydroxyl measurements and atmospheric oxidation in a California forest, Atmos. Chem. Phys., 12, 8009-8020, doi:10.5194/acp-12-8009-2012, 2012.

Massman, W. J.: A review of the molecular diffusivities of $\mathrm{H}_{2} \mathrm{O}$, $\mathrm{CO}_{2}, \mathrm{CH}_{4}, \mathrm{CO}, \mathrm{O}_{3}, \mathrm{SO}_{2}, \mathrm{NH}_{3}, \mathrm{~N}_{2} \mathrm{O}$ and $\mathrm{NO}_{2}$ in air, $\mathrm{O}_{2}$ and $\mathrm{N}_{2}$ near STP, Atmos. Environ., 32, 1111-1127, 1998.

Meyers, T. P. and Dale, R. F.: Predicting daily insolation with hourly cloud height and coverage, J. Clim. Appl. Meteorol., 22, 537545, 1983 .

Meyers, T. P. and Paw U, K. T.: Testing of a higher-order closure model for modeling airflow within and above plant canopies, Bound.-Lay. Meteorol., 37, 297-311, 1986.

Meyers, T. P., Finkelstein, P., Clarke, J., Ellestad, T. G., and Sims, P. F.: A multilayer model for inferring dry deposition using standard meteorological measurements, J. Geophys. Res., 103, 22645-22661, 1998.

Mogensen, D., Smolander, S., Sogachev, A., Zhou, L., Sinha, V., Guenther, A., Williams, J., Nieminen, T., Kajos, M. K., Rinne, J., Kulmala, M., and Boy, M.: Modelling atmospheric OH-reactivity in a boreal forest ecosystem, Atmos. Chem. Phys., 11, 97099719, doi:10.5194/acp-11-9709-2011, 2011.

Mollner, A. K., Valluvadasan, S., Feng, L., Sprague, M. K., Okumura, M., Milligan, D. B., Bloss, W. J., Sander, S. P., Martien, P. T., Harley, R. A., McCoy, A. B., and Carter, W. P. L.: Rate of gas phase association of hydroxyl radical and nitrogen dioxide, Science, 330, 646-649, 2010.

Naik, V., Delire, C., and Wuebbles, D. J.: Sensitivity of global isoprenoid emissions to climate variability and atmospheric $\mathrm{CO}_{2}, \mathrm{~J}$. Geophys. Res., 109, D06301, doi:10.1029/2003JD004236, 2004.

Ortiz-Montalvo, D. L., Lim, Y. B., Perri, M. J., Seitzinger, S. P., and Turpin, B. J.: Volatility and yield of glycolaldehyde SOA formed through aqueous photochemistry and droplet evaporation, Aerosol Sci. Technol., 46, 1002-1014, 2012.

Patankar, S. V.: Numerical Heat Transfer and Fluid Flow, Hemisphere Publishing Corp., Washington, D.C., 1980.

Paulot, F., Crounse, J. D., Kjaergaard, H. G., Kurten, A., St Clair, J. M., Seinfeld, J. H., and Wennberg, P. O.: Unexpected epoxide formation in the gas-phase photooxidation of isoprene, Science, 325, 730-733, 2009.

Perry, D. A., Oren, R., and Hart, S. C.: Forest Ecosystems, 2nd Edn., The Johns Hopkins University Press, Baltimore, Maryland, 2008.

Peeters, J. and Müller, J. F.: $\mathrm{HO}_{\mathrm{x}}$ radical regeneration in isoprene oxidation via peroxy radical isomerisations. II: experimental evidence and global impact, Phys. Chem. Chem. Phys., 12, 1422714235, 2010.
Poisson, N., Kanakidou, M., and Crutzen, P. J.: Impact of nonmethane hydrocarbons on tropospheric chemistry and the oxidizing power of the global troposphere: 3-dimensional modeling results, J. Atmos. Chem., 36, 157-230, 2000.

Potter, C. S.: Terrestrial biomass and the effects of deforestation on the global carbon cycle, BioScience, 49, 769-778, 1999.

Pugh, T. A. M., MacKenzie, A. R., Hewitt, C. N., Langford, B., Edwards, P. M., Furneaux, K. L., Heard, D. E., Hopkins, J. R., Jones, C. E., Karunaharan, A., Lee, J., Mills, G., Misztal, P., Moller, S., Monks, P. S., and Whalley, L. K.: Simulating atmospheric composition over a South-East Asian tropical rainforest: performance of a chemistry box model, Atmos. Chem. Phys., 10, 279-298, doi:10.5194/acp-10-279-2010, 2010.

Raupach, M. R.: A practical Lagrangian method for relating scalar concentrations to source distributions in vegetation canopies, Q. J. Roy. Meteor. Soc., 115, 609-632, 1989a.

Raupach, M. R.: Applying Lagrangian fluid mechanics to infer scalar source distributions from concentration profiles in plant canopies, Agr. Forest Meteorol., 47, 85-108, 1989 b.

Raupach, M. R. and Thom, A. S.: Turbulence in and above plant canopies, Annu. Rev. Fluid Mech., 13, 97-129, 1981.

Raupach, M. R., Finnigan, J. J., and Brunet, Y.: Coherent eddies and turbulence in vegetation canopies: The mixing-layer analogy, Bound.-Lay. Meteorol., 78, 351-382, 1996.

Rinne, J., Taipale, R., Markkanen, T., Ruuskanen, T. M., Hellén, H., Kajos, M. K., Vesala, T., and Kulmala, M.: Hydrocarbon fluxes above a Scots pine forest canopy: measurements and modeling, Atmos. Chem. Phys., 7, 3361-3372, doi:10.5194/acp-73361-2007, 2007.

Rinne, J., Markkanen, T., Ruuskanen, T. M., Petäjä, T., Keronen, P., Tang, M. J., Crowley, J. N., Rannik, Ü., and Vesala, T.: Effect of chemical degradation on fluxes of reactive compounds - a study with a stochastic Lagrangian transport model, Atmos. Chem. Phys., 12, 4843-4854, doi:10.5194/acp-12-4843-2012, 2012.

Ropp, D. L. and Shadid, J. N.: Stability of operator splitting methods for systems with indefinite operators: Advection-diffusionreaction systems, J. Comput. Phys., 228, 3508-3516, 2009.

Sander, S. P., Friedl, R. R., Abbatt, J., Barker, J., Burkholder, J., Golden, D., Kolb, C, Kurylo, M., Moortgat, G., Wine, P., Huie, R., and Orkin, V.: Chemical Kinetics and Photochemical Data for Use in Atmospheric Studies, Evaluation Number 17, NASA Jet Propulsion Laboratory, JPL Publication 10-6, Pasadena, California, 2011.

Sander, R.: Compilation of Henry's Law Constants for Inorganic and Organic Species of Potential Importance in Environmental Chemistry, Version 3, http://www.henrys-law.org, last access: 15 March 2012, 1999.

Saunders, S. M., Jenkin, M. E., Derwent, R. G., and Pilling, M. J.: Protocol for the development of the Master Chemical Mechanism, MCM v3 (Part A): tropospheric degradation of nonaromatic volatile organic compounds, Atmos. Chem. Phys., 3, 161-180, doi:10.5194/acp-3-161-2003, 2003.

Schichtel, B. A., Malm, W. C., Bench, G., Fallon, S., McDade, C. E., Chow, J. C., and Watson, J. G.: Fossil and contemporary fine particulate carbon fractions at 12 rural and urban sites in the United States, J. Geophys. Res., 113, D02311, doi:10.1029/2007JD008605, 2008.

Schmid, H. P., Su, H. B., Vogel, C. S., and Curtis, P. S.: Ecosystematmosphere exchange of carbon dioxide over a mixed hardwood 
forest in northern lower Michigan, J. Geophys. Res., 108, 44174436, 2003.

Shaw, R. H.: Secondary wind maxima inside plant canopies, J. Appl. Meteorol., 16, 514-521, 1977.

Strang, G.: On the construction and comparison of difference schemes, SIAM Journal of Numerical Analysis, 5, 506-517, 1968.

Strong, C., Fuentes, J. D., and Baldocchi, D.: Reactive hydrocarbon footprints during canopy senescence, Agr. Forest Meteorol., 127, 159-173, 2004.

Steiner, A. L., Pressley, S. N., Botros, A., Jones, E., Chung, S. H., and Edburg, S. L.: Analysis of coherent structures and atmosphere-canopy coupling strength during the CABINEX field campaign, Atmos. Chem. Phys., 11, 11921-11936, doi:10.5194/acp-11-11921-2011, 2011.

Steinkamp, J. and Lawrence, M. G.: Improvement and evaluation of simulated global biogenic soil NO emissions in an AC-GCM, Atmos. Chem. Phys., 11, 6063-6082, doi:10.5194/acp-11-60632011, 2011.

Stockwell, W. R. and Forkel, R.: Ozone and volatile hydrocarbons: isoprene, terpenes, aldehydes, and organic acids, in: Tree Physiology, Vol. 3. Trace Gas Exchange in Forest Ecosystems, edited by: Gasche, R., Papen, H., and Rennenberg, H., Kluwer Academic Publishers, Dordrecht, 257-276, 2002.

Stockwell, W. R., Kirchner, F., Kuhn, M., and Seefeld, S.: A new mechanism for regional atmospheric chemistry modeling, J. Geophys. Res., 102, 25847-25879, 1997.

Stone, D., Evans, M. J., Edwards, P. M., Commane, R., Ingham, T., Rickard, A. R., Brookes, D. M., Hopkins, J., Leigh, R. J., Lewis, A. C., Monks, P. S., Oram, D., Reeves, C. E., Stewart, D., and Heard, D. E.: Isoprene oxidation mechanisms: measurements and modelling of $\mathrm{OH}$ and $\mathrm{HO}_{2}$ over a South-East Asian tropical rainforest during the OP3 field campaign, Atmos. Chem. Phys., 11, 6749-6771, doi:10.5194/acp-11-6749-2011, 2011.

Stroud, C., Makar, P., Karl, T., Guenther, A., Geron, C., Turnipseed, A., Nemitz, E., Baker, B., Potosnak, M., and Fuentes, J. D.: Role of canopy-scale photochemistry in modifying biogenicatmosphere exchange of reactive terpene species: Results from the CELTIC field study, J. Geophys. Res., 110, D17303, doi:10.1029/2005JD005775, 2005.

Sullivan, A. P. and Weber, R. J.: Chemical characterization of the ambient organic aerosol soluble in water: 2. Isolation of acid, neutral, and basic fractions by modified sizeexclusion chromatography, J. Geophys. Res., 111, D05315, doi:10.1029/2005JD006486, 2006.

Surratt, J. D., Murphy, S. M., Kroll, J. H., Ng, N. L., Hildebrandt, L., Sorooshian, A., Szmigielski, R., Vermeylen, R., Maenhaut, W., Claeys, M., Flagan, R. C., and Seinfeld, J. H.: Chemical composition of secondary organic aerosol formed from the photooxidation of isoprene, J. Phys. Chem. A, 110, 9665-9690, 2006.

Tan, D., Faloona, I., Simpas, J. B., Brune, W., Shepson, P. B., Couch, T. L., Sumner, A. L., Carroll, M. A., Thornberry, T., Apel, E., Riemer, D., and Stockwell, W.: $\mathrm{HO}_{\mathrm{x}}$ budgets in a deciduous forest: Results from the PROPHET summer 1998 campaign, J. Geophys. Res., 106, 24407-24427, 2001.

Tanner, R. L. and Parkhurst, W. J.: Chemical composition of fine particles in the Tennessee Valley region, J. Air Waste Manage., 50, 1299-1307, 2000.
Tanner, R. L., Parkhurst, W. L., and McNichol, A. P.: Fossil sources of ambient aerosol carbon based on ${ }^{14} \mathrm{C}$ measurements, Aerosol Sci. Tech., 38, 133-139, 2004.

Trainer, M., Williams, E. J., Parrish, D. D., Buhr, M. P., Allwine, E. J., Westberg, H. H., Fehsenfeld, F. C., and Liu, S. C.: Models and observations of the impact of natural hydrocarbons on rural ozone, Nature, 329, 705-707, 1987.

Tracy, C. R., Weich, W. R., and Porter, W. P.: Properties of Air: A Manual for Use in Biophysical Ecology, 3rd Edn., Tech. Rep. No. 1, Laboratory for Biophysical Ecology, University of WisconsinMadison, Madison, 1980.

Ulke, A. G.: New turbulent parameterization for a dispersion model in the atmospheric boundary layer, Atmos. Environ., 34, 1029$1042,2000$.

Wagner, W. and Pruss, A.: International equations for the saturation properties of ordinary water substance. Revised according to the International Temperature Scale of 1990, Addendum to J. Phys. Chem. Ref. Data 16, 893, 1987, J. Phys. Chem. Ref. Data, 22, 783-787, 1993.

Weber, R. J., Sullivan, A. P., Peltier, R. E., Russell, A. G., Yan, B., Zheng, M., de Gouw, J., Warneke, C., Brock, C., Holloway, J. S., Atlas, E. L., and Edgerton, E. S.: A study of secondary organic aerosol formation in the anthropogenicinfluenced southeastern United States, J. Geophys. Res., 112, D13302, doi:10.1029/2007JD008408, 2007.

Weber, R. O.: Remarks on the definition and estimation of friction velocity, Bound.-Lay. Meteorol., 93, 197-209, 1999.

Wesely, M. L.: Parameterization of surface resistances to gaseous dry deposition in regional-scale numerical models, Atmos. Environ., 23, 1293-1304, 1989.

Wiedinmyer, C., Greenberg, J., Guenther, A., Hopkins, B., Baker, K., Geron, C., Palmer, P. I., Long, B. P., Turner, J. R., Petron, G., Harley, P., Pierce, T. E., Lamb, B., Westberg, H., Baugh, W., Koerber, M., and Janssen, M.: Ozarks Isoprene Experiment (OZIE): Measurements and modeling of the "isoprene volcano", J. Geophys. Res., 110, D18307, doi:10.1029/2005JD005800, 2005.

Williams, E. J., Guenther, A., and Fehsenfeld, F. C.: An inventory of nitric oxide emissions from soils in the United States, J. Geophys. Res., 97, 7511-7519, 1992.

Wilson, N. R. and Shaw, R. H.: A higher order closure model for canopy flow, J. Appl. Meteorol., 16, 1197-1205, 1977.

Wolfe, G. M. and Thornton, J. A.: The Chemistry of AtmosphereForest Exchange (CAFE) Model - Part 1: Model description and characterization, Atmos. Chem. Phys., 11, 77-101, doi:10.5194/acp-11-77-2011, 2011.

Wolfe, G. M., Thornton, J. A., Bouvier-Brown, N. C., Goldstein, A. H., Park, J.-H., McKay, M., Matross, D. M., Mao, J., Brune, W. H., LaFranchi, B. W., Browne, E. C., Min, K.-E., Wooldridge, P. J., Cohen, R. C., Crounse, J. D., Faloona, I. C., Gilman, J. B., Kuster, W. C., de Gouw, J. A., Huisman, A., and Keutsch, F. N.: The Chemistry of Atmosphere-Forest Exchange (CAFE) Model - Part 2: Application to BEARPEX-2007 observations, Atmos. Chem. Phys., 11, 1269-1294, doi:10.5194/acp-11-12692011, 2011a.

Wolfe, G. M., Thornton, J. A., McKay, M., and Goldstein, A. H.: Forest-atmosphere exchange of ozone: sensitivity to very reactive biogenic VOC emissions and implications for incanopy photochemistry, Atmos. Chem. Phys., 11, 7875-7891, doi:10.5194/acp-11-7875-2011, 2011 b. 
Wolfe, G. M., Crounse, J. D., Parrish, J. D., St. Clair, J. M., Beaver, M. R., Paulot, F., Yoon, T. P., Wennberg, P. O., and Keutsch, F. N.: Photolysis, $\mathrm{OH}$ reactivity and ozone reactivity of a proxy for isoprene-derived hydroperoxyenals (HPALDs), Phys. Chem. Chem. Phys., 14, 7276-7286, 2012.

Wu, Y., Brashers, B., Finkelstein, P., and Pleim, J. E.: A multilayer biochemical dry deposition model. 1. Model formulation, J. Geophys. Res., 108, 4013, doi:10.1029/2002JD002293, 2003.

Yaws, C. L., Bu, L., and Li, K. Y.: Chapter 5. Diffusion Coefficients in Air, in: Handbook of Transport Property Data: Viscosity, Thermal Conductivity and Diffusion Coefficients of Liquids and Gases, edited by: Yaws, C. L., Gulf Publishing Co., Houston, TX, 117-138, 1995.

Yienger, J. J. and Levy II, H.: Empirical model of global soilbiogenic $\mathrm{NO}_{\mathrm{x}}$ emissions, J. Geophys. Res., 100, 11447-11464, 1995.
Zaveri, R. A., Easter, R. C., Fast, J. D., and Peters, L. K.: Model for Simulating Aerosol Interactions and Chemistry (MOSAIC), J. Geophys. Res., 113, D13204, doi:10.1029/2007JD008782, 2008.

Zhang, L., Moran, M., Makar, P., Brook, J., and Gong, S.: Modeling gaseous dry deposition in AURAMS: A Unified Regional Airquality Modeling System, Atmos. Environ., 36, 537-560, 2002.

Zhang, L., Brook, J. R., and Vet, R.: A revised parameterization for gaseous dry deposition in air-quality models, Atmos. Chem. Phys., 3, 2067-2082, doi:10.5194/acp-3-2067-2003, 2003.

Zhang, X., Liu, Z., Hecobian, A., Zheng, M., Frank, N. H., Edgerton, E. S., and Weber, R. J.: Spatial and seasonal variations of fine particle water-soluble organic carbon (WSOC) over the southeastern United States: implications for secondary organic aerosol formation, Atmos. Chem. Phys., 12, 6593-6607, doi:10.5194/acp-12-6593-2012, 2012. 